\title{
Climate change threatens archaeologically significant ice patches: insights into their age, internal structure, mass balance and climate sensitivity
}

\author{
Rune Strand Ødegård ${ }^{1}$, Atle Nesje ${ }^{2}$, Ketil Isaksen ${ }^{3}$, Liss Marie Andreassen ${ }^{4}$, Trond Eiken ${ }^{5}$, Margit Schwikowski $^{6}$, \\ and Chiara Uglietti ${ }^{6}$ \\ ${ }^{1}$ Norwegian University of Science and Technology, Gjøvik, Norway \\ ${ }^{2}$ University of Bergen, Bergen, Norway \\ ${ }^{3}$ Norwegian Meteorological Institute, Oslo, Norway \\ ${ }^{4}$ Norwegian Water Resources and Energy Directorate, Oslo, Norway \\ ${ }^{5}$ Department of Geosciences, University of Oslo, Oslo, Norway \\ ${ }^{6}$ Paul Scherrer Institute, Villigen, Switzerland
}

Correspondence to: Rune Strand Ødegård (rune.oedegaard@ ntnu.no)

Received: 19 April 2016 - Published in The Cryosphere Discuss.: 23 May 2016

Revised: 21 November 2016 - Accepted: 26 November 2016 - Published: 2 January 2017

\begin{abstract}
Despite numerous spectacular archaeological discoveries worldwide related to melting ice patches and the emerging field of glacial archaeology, governing processes related to ice patch development during the Holocene and their sensitivity to climate change are still largely unexplored. Here we present new results from an extensive 6year (2009-2015) field experiment at the Juvfonne ice patch in Jotunheimen in central southern Norway. Our results show that the ice patch has existed continuously since the late Mesolithic period. Organic-rich layers and carbonaceous aerosols embedded in clear ice show ages spanning from modern at the surface to ca. 7600 cal years BP at the bottom. This is the oldest dating of ice in mainland Norway. The expanding ice patch covered moss mats appearing along the margin of Juvfonne about 2000 years ago. During the study period, the mass balance record showed a strong negative balance, and the annual balance is highly asymmetric over short distances. Snow accumulation is poorly correlated with estimated winter precipitation, and single storm events may contribute significantly to the total winter balance. Snow accumulation is approx. $20 \%$ higher in the frontal area compared to the upper central part of the ice patch. There is sufficient meltwater to bring the permeable snowpack to an isothermal state within a few weeks in early summer. Below the seasonal snowpack, ice temperatures are between -2 and
\end{abstract}

$-4{ }^{\circ} \mathrm{C}$. Juvfonne has clear ice stratification of isochronic origin.

\section{Introduction}

The emergence of glacial archaeology is described by Andrews and Mackay (2012) and Dixon et al. (2014). In archaeology, the term "glacial archaeology" or "snow patch archaeology" refers to several alpine contexts in different regions of the world (Callanan, 2010). The release of Ötzi's 5300-yearold body from the ice in northern Italy marked the beginning of a number of remarkable archaeological discoveries worldwide connected to melting ice and thawing permafrost in the high mountains (Spindler, 1994). Discoveries are known from the Alps (Grosjean et al., 2007; Suter et al., 2005), mummies in Greenland (Hansen et al., 1985) and the Andes Mountains (Ceruti, 2004), and from archaeological finds at retreating ice patches in North America (Brunswig, 2014; Dixon et al., 2005; Farnell et al., 2004; Hare et al., 2012; Lee, 2012; Meulendyk et al., 2012). When analysing the number of artefacts on a global scale during the Holocene, there is a negative correlation between periods of glacial advance and the number of artefacts. This is particularly the case in the Alps and North America (Reckin, 2013), but a similar pattern 
is also found in Norway (Nesje et al., 2012). The question is if this is caused by changes in climate-dependent preservation conditions or decreased human use of these areas in periods of cold climate.

In Norway, there has been an increasing focus on ice patches since the extreme melting in southern Norway in the autumn of 2006. There are about 3000 known artefact finds globally from ice patches. Most of these have melted out during the last 3 decades. Approximately 2000 of these archaeological finds are in central southern Norway, making it by far the most find-rich region in the world (Curry, 2014; Lars Pilø, personal communication, 2014). Among the most spectacular finds are a Bronze Age leather shoe that melted out in late autumn 2006 and a well-preserved tunic dated between 230 and 390 (Common Era) CE (Finstad and Vedeler, 2008; Vedeler and Jørgensen, 2013). The shoe was dated to be around 3400 years old (1429-1257 Before Common Era, BCE), and is by far the oldest shoe found in Norway. Dates are given in calibrated ages (BCE or CE), including 1 sigma errors $(\sigma)$ when referencing archaeological finds in Norway. Radiocarbon dates from ice patches are referenced as calibrated years Before Present $(B P=1950 \mathrm{CE})$.

The geoscience of old ice patches is still in its infancy and the geoscience literature about ice patches is sparse compared to glacial archaeology. Within the glaciological community it is commonly differentiated between glaciers and snowfields and active or inactive ice (UNESCO, 1970). Snowfields may be seasonal or perennial. Seasonal snowfields melt during the summer. Perennial snowfields exist for 2 or more years. Smaller ice bodies without significant movement may be remnants of a past active glacier or a perennial snowfield and are commonly referred to as glacierets. In this paper, we use ice patch for perennial snowfields and glacierets. Ice patches are, in contrast to glaciers, mostly stagnant and therefore do not convey mass from an accumulation towards an ablation area. In fact, ice patches often do not exhibit distinct glacier facies such as a firn area. In the wet-snow zone, the transformation of snow to ice occurs rapidly by metamorphism and refreezing of meltwater (Kawasaki et al., 1993). Ice patches and surrounding terrain are generally underlain by permafrost (Haeberli et al., 2004). There are few studies related to their thermal regime, mass balance and dynamics (Eveland et al., 2013; Fukui, 2003; Fukui and Iida, 2011; Sato et al., 1984). Fujita et al. (2010) concluded that ice patches exist below the regional equilibrium-line altitude (ELA) of glaciers. A study by Glazirin et al. (2004) showed that they can modify the nearby wind field. The studies mentioned documented feedbacks between ice patch size and both summer ablation and winter snow accumulation. The spatial variability of the turbulent fluxes in alpine terrain is of particular interest to ice patches. Ice patches are influenced by advective heat transfer in summer (Essery et al., 2006; Mott et al., 2015; Pohl et al., 2006).

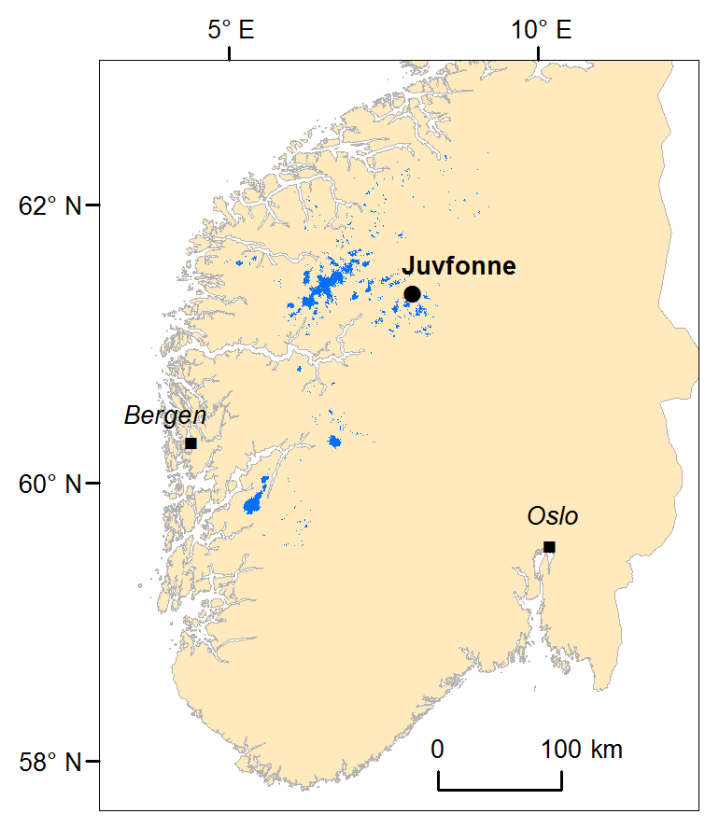

Figure 1. The field site Juvfonne in central southern Norway. Dark blue areas are glaciers.

Despite some progress in these studies, the state of knowledge is not at a level to design reliable models of how ice patches have developed during the Holocene and to evaluate their sensitivity to future climate changes. The main objective of this study is to help fill this knowledge gap based on a 6-year field experiment at the Juvfonne ice patch (Figs. 1 and 2), located in Jotunheimen in central southern Norway.

The overall objective of this study is to better understand the governing processes of ice patch mass balance and Holocene development. A multi-disciplinary approach was chosen, combining a set of new geophysical data, radiocarbon dating, mass balance measurements and visual observations from two 30-70 m tunnels that were excavated into the central parts of the ice patch to better understand (1) the age, (2) the mass balance, (3) the thermal regime, (4) ice layering and deformation on Holocene timescale, and finally (5) the physical processes relevant to artefact displacement and preservation.

\section{Field site and physical setting}

In central southern Norway archaeologists have so far identified more than 65 sites with finds related to ice patches, but many sites with potential finds have not been checked in the field. The archaeological finds are related to reindeer hunting. The snowfields are an important refuge for reindeer during hot summer days, giving them relief from pestering insects. The focus of this study is the ice patch Juvfonne $\left(61.676^{\circ} \mathrm{N}, 8.354^{\circ} \mathrm{E}\right)$ and the surrounding terrain (Figs. 1 and 2). This site is a well-preserved Iron Age hunting 


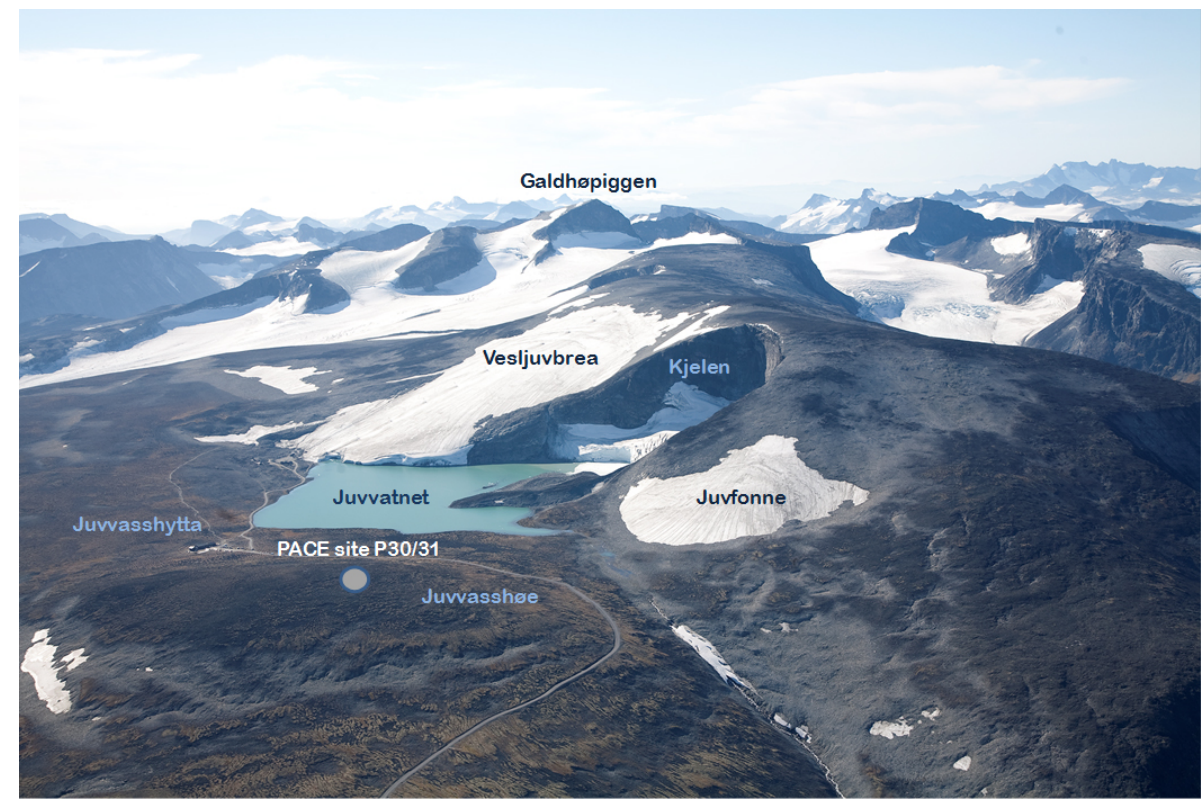

Figure 2. Overview picture from September 2008 towards SSW showing Juvfonne and the Juvflye area including Kjelen, Juvvatnet, Juvvasshytta, Vesljuvbrea and the P30/31 Permafrost and Climate in Europe (PACE) boreholes at Juvvasshøe. Also visible is the highest mountain of Norway, Galdhøpiggen (2469 m a.s.1.). Photo: Helge J. Standal.

"station" documented by more than 600 registered wooden artefacts and 50 hunting blinds. Radiocarbon dating of artefacts shows ages in two separate time intervals, 246-534 and 804-898 CE (Nesje et al., 2012). The geoscience studies at Juvfonne started in 2009 (Ødegård et al., 2011). Nesje et al. (2012) gave a comprehensive presentation and discussion of archaeological finds in central southern Norway related to late Holocene climate history.

The width of the ice patch is approx. $500 \mathrm{~m}$, with an upslope length of $350 \mathrm{~m}$. Juvfonne had an area of $0.15 \mathrm{~km}^{2}$ and ranged in altitude from 1839 to $1993 \mathrm{~m}$ a.s.l. in 2010 (Andreassen, 2011). The mean surface slope is $17^{\circ}$ and the ice patch has a north-easterly aspect.

Due to snowdrift by prevailing westerly winds during the accumulation season, Juvfonne is below the regional temperature-precipitation equilibrium-line altitude (TP-ELA). Annual surface mass balance measurements were conducted on three glaciers (since 1949 at Storbreen and 1962 at Hellstugubreen and Gråsubreen) in the Jotunheimen mountainous region (Andreassen et al., 2005; Andreassen and Winsvold, 2012). The ELA increases with distance from the coast from $1780 \mathrm{~m}$ a.s.l. at Storbreen to $2150 \mathrm{~m}$ a.s.l. at Gråsubreen (Kjøllmoen et al., 2011). Except for a transient mass surplus from 1989 to 1995 due to increased winter precipitation in this period, the glaciers have lost mass. Map surveys and inventory data show a reduction in area of the glaciers in Jotunheimen of about $10 \%$ from the 1960s to 2003 (Andreassen et al., 2008).

Juvfonne is well within the mountainous permafrost zone. Present permafrost thicknesses at elevations where we find perennial ice patches $(\sim>1700 \mathrm{~m}$ a.s.l.) can be estimated to be more than $100 \mathrm{~m}$. Observations of ground thermal regimes (Farbrot et al., 2011; Harris et al., 2009), bottom temperature of snow cover (BTS) (Farbrot et al., 2011; Isaksen et al., 2002; Ødegård, 1993) and geophysical surveys to delineate the altitudinal limit of the permafrost (Hauck et al., 2004; Isaksen et al., 2011), along with spatial numerical equilibrium and transient permafrost models (Gisnås et al., 2013, 2016; Hipp et al., 2012; Westermann et al., 2013), indicate a lower limit of permafrost at $1450-1600 \mathrm{~m}$ a.s.l. in the area.

Juvfonne is at a distance of $750 \mathrm{~m}$ and at the same elevation as the permafrost boreholes (the P30 and 31 Permafrost and Climate in Europe (PACE) boreholes) and climate monitoring site at Juvvasshøe (Sollid et al., 2000) (see Fig. 2). The site has a record of ground temperatures and meteorological observations since September 1999. Mean annual air temperature for the period $2000-2015$ is $-3.5^{\circ} \mathrm{C}$. At $15 \mathrm{~m}$ depth, the permafrost temperature ranges from a minimum of $-3.1{ }^{\circ} \mathrm{C}$ in 1999 to a maximum of $-2.5^{\circ} \mathrm{C}$ recorded in 2008. The active layer thickness has varied between 2.0 and $2.4 \mathrm{~m}$ and permafrost thickness is estimated to exceed $300 \mathrm{~m}$ (Isaksen et al., 2011). In 2008, an altitudinal transect of boreholes and adjacent air temperature sensors were installed at three sites ranging from shallow seasonal frost to permafrost (Farbrot et al., 2011).

For the period 1961-1990, the mean annual precipitation is estimated to be between 800 and $1000 \mathrm{~mm} \mathrm{a}^{-1}$ at 1900 m a.s.l. at Juvfonne (Norwegian Meteorological Institute, unpublished data). 
Sediment cores in the nearby Juvvatnet were used to reconstruct the glacier activity of Kjelebrea and Vesljuvbrea (Nesje et al., 2012) following the methodology described by Bakke et al. (2010). The results indicate that the late Holocene variations of these glaciers are largely in agreement with size variations of other glaciers in the Jotunheimen area (Matthews and Dresser, 2008; Nesje, 2009). Lichenometry suggests that the margin of Juvfonne extended $\sim 250 \mathrm{~m}$ from its present position during the "Little Ice Age" (LIA) maximum extent in the mid-18th century (Nesje et al., 2012).

\section{Methods}

\subsection{Georadar}

The ice patch was surveyed by a RAMAC georadar on 23 September 2009 and 1 March 2012, using a highfrequency antenna of $250 \mathrm{MHz}$. The dielectric constant of ice was set to be 3.2 , giving a phase velocity of $168 \mathrm{~m} \mathrm{ss}^{-1}$. Georadar data and positioning data from the Global Navigation Satellite System (GNSS) were manually digitized to obtain a point dataset of ice thickness and bed topography. The point datasets were interpolated to get an ice thickness map and a digital terrain model (DTM) of the ice patch bed. Obvious artefacts in the resulting data caused by the interpolation technique were manually removed. A total of 40 independent control points gave an estimated standard deviation in bed elevation of $1.1 \mathrm{~m}$ and a maximum error of $2.6 \mathrm{~m}$. The control points were obtained by point measurements (GNSS) in the recently exposed area.

\subsection{Laser scanning}

The ice patch and surrounding terrain were scanned with an airborne laser (Leica ALS70) on 17 September 2011. The company COWI A/S, on assignment from the Norwegian Water Resources and Energy Directorate, carried out the laser scanning and the processing of the data. The flight altitude was 3080-3600 ma.s.l. The area was scanned with 5 points per $\mathrm{m}^{2}$. Quality controls and accuracy assessments revealed accuracy better than $0.1 \mathrm{~m}$ in surface elevation. Aerial photos were taken on the same day. These data were used to produce a high-quality DTM and orthophotos of the ice patch surface and surrounding terrain. The DTM was resampled to a resolution of $1 \mathrm{~m}$.

\subsection{Mass balance and front measurements}

Surface mass balance measurements of winter accumulation (snow depth at 20-60 sites and density at one site) and ablation (at one to four stakes) were made following standard methods for the melting seasons of 2010-2015 (Andreassen, 2011). Distance to the terminus was measured from two points outside the ice patch (Fig. 3a) in August or early September using a laser distance metre.

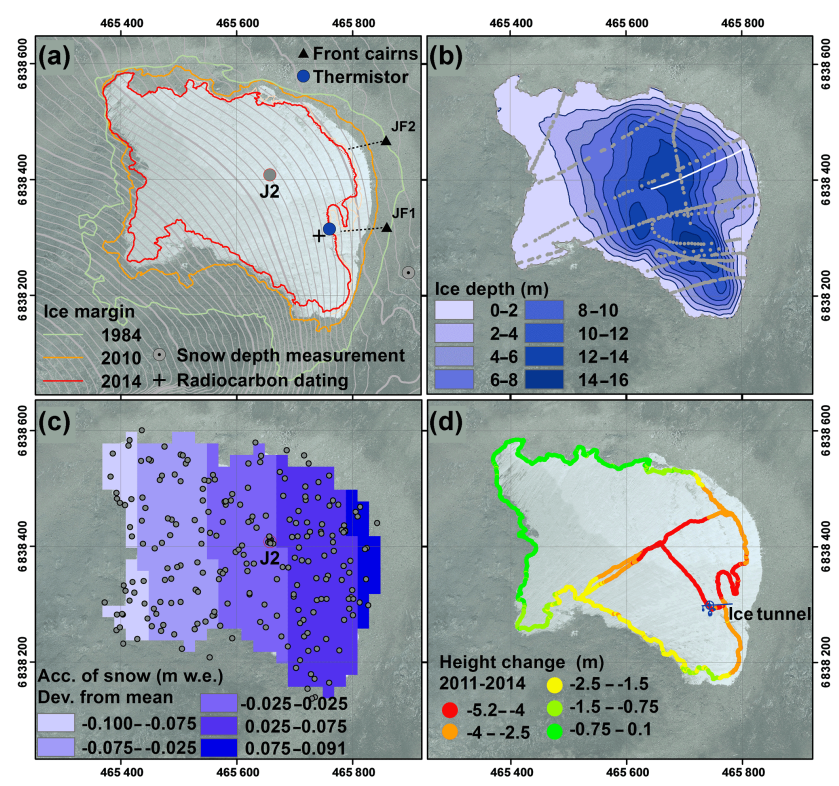

Figure 3. Maps of Juvfonne with orthophotos from September 2011 as background (UTM coordinates zone $32^{\circ} \mathrm{N}$ ): (a) ice margins, position of front measurements (JF1 and JF2, see Fig. 9), position of mass balance stake $\mathrm{J} 2$, position of thermistor for ice temperature measurements (Fig. 13) and position of the oldest radiocarbon dating and position of snow depth measurement station; (b) interpolated contours of bed topography relative to ice thickness in September 2011 (grey markers are radar points used in the interpolation) and position of the georadar track in Fig. 4, white line; (c) grey markers are snow depth measurements (2010-2015), while the raster map shows a first order polynomial fit to the deviation from mean accumulation each year; and (d) height differences along GNSS tracks in 2014 relative to ice surface from laser data in 2011 and positions of the ice tunnel excavated in 2012.

The extent of the Juvfonne ice patch was surveyed by foot with GNSS with a Topcon receiver mounted on a backpack and one reference receiver mounted in a fixed base point (Fig. 3a, Table 1). The GNSS data were processed with Topcon software TTOOLS version 8 .

Surveys were done annually in August or September from 2010 to 2015 , but the survey from 2012 was only done along the lower part due to snow conditions. Areal extent was also determined by digitizing outlines from orthophotos from 2011 and from topographical maps in 1981 and 2004 (map product coded N50 from the Norwegian mapping authorities). Furthermore, outlines from Landsat inventories from 1997 and 2003 were used (Andreassen et al., 2008; Winsvold et al., 2014). The accuracy of the differential GNSS is within $1 \mathrm{~m}$, the accuracy of the topographic maps within $5 \mathrm{~m}$ and the accuracy of the Landsat mapping within $30 \mathrm{~m}$. The standard deviation in height of the GNSS measurements is in the range $0.1-0.2 \mathrm{~m}$, giving \pm 2 standard deviations of $0.6 \mathrm{~m}$. 
Table 1. Areal extents of Juvfonne derived from topographic maps, Landsat imagery, GNSS measurements by foot and digitizing from orthophotos.

\begin{tabular}{lllr}
\hline Year & Date & Source & Area $\left(\mathrm{km}^{2}\right)$ \\
\hline 1981 & & Map & 0.171 \\
1984 & 10 Aug 1984 & Orthophoto & 0.208 \\
1997 & 15 Aug 1997 & Landsat & 0.208 \\
2003 & 09 Aug 2013 & Landsat & 0.150 \\
2004 & 12 Aug 2004 & Map & 0.187 \\
2010 & 25 Aug 2010 & GNSS & 0.149 \\
2011 & 02 Aug 2011 & GNSS & 0.150 \\
2011 & 17 Sep 2011 & Orthophoto & 0.127 \\
2012 & 12 Sep 2012 & GNSS & 0.160 \\
2013 & 12 Aug 2013 & GNSS & 0.151 \\
2014 & 09 Sep 2014 & GNSS & 0.101 \\
2015 & 11 Sep 2015 & GNSS & $0.186^{*}$ \\
\hline
\end{tabular}

* Seasonal snow remaining along the extent.

\subsection{Meteorological measurements}

Hourly meteorological data were obtained from the automatic weather station (AWS) at Juvvasshøe (1894 m a.s.l.). Juvvasshøe is the highest official meteorological station in Norway and is freely exposed and considered representative for this study. Due to the sheltered setting of Juvfonne compared to Juvvasshøe, the wind speed at Juvvasshøe is generally higher. However, wind data from Juvvasshøe give important information on wind direction and wind speed relevant to snow accumulation and ablation processes at Juvfonne. The first station was set up in 1999 (Isaksen et al., 2003) and a new official weather station was established at the same site in June 2009. One additional station recording hourly snow depth was set up in autumn 2011 in front of Juvfonne (95 m from the eastern margin of the snowfield). Hourly data on snow depth are scarce in the high mountains in Scandinavia. Observed air temperature and wind speed at Juvvasshøe were compared with the 1971-2000 climatological normal based on interpolated air temperature data from seNorge (Engeset et al., 2004) and daily observations of wind speed from Fokstugu (973 m a.s.1.), $70 \mathrm{~km} \mathrm{NE}$ of Juvvasshøe, which was the best nearby correlated meteorological station that had long time series.

A thermistor cable was installed in a $10 \mathrm{~m}$ deep borehole in 2009 to record ice temperatures. Temperatures were recorded every $3 \mathrm{~h}$ until late September 2011 with an accuracy of $0.05^{\circ} \mathrm{C}$ ( 1 standard deviation). The entire thermistor cable melted out in September 2014. Additional thermistor measurements were made in the snow and ice at the onset of thaw in spring 2010.

\subsection{Radiocarbon dating}

In May 2010, a $30 \mathrm{~m}$ long ice tunnel was excavated in the Juvfonne ice patch. During spring 2012, a new $70 \mathrm{~m}$ long tunnel was excavated into the central parts of the ice patch. The tunnels were excavated with specially designed ice axes, causing minimal disturbance to the surrounding ice. The tunnels gave an excellent opportunity to verify the radar data and to collect organic material and ice for radiocarbon dating. Dateable organic material is available, but there are no continuous layers of organic material. Radiocarbons dating prior to 2012 are published in Nesje et al., 2012; Zapf et al., 2013 and Ødegård et al., 2011. Conventional ${ }^{14} \mathrm{C}$ ages were calibrated using OxCal v4.2.4 software (Bronk Ramsey and Lee, 2013) with the IntCal13 calibration curve (Reimer et al., 2013).

The organic debris was collected from the walls, below the floor of the ice tunnels (five samples from the tunnel excavated in 2010 and five samples from the tunnel excavated in 2012, Table 2) and from organic debris melting out at the front, of which two datings are reported in this paper. Nine additional datings were published by Nesje et al. (2012).

The recently developed method for radiocarbon dating of ice utilizes the organic carbon fraction of carbonaceous aerosols scavenged from the atmosphere during snowfall and embedded into the ice matrix (Jenk et al., 2009; Sigl et al., 2009; Uglietti et al., 2016). This method was tested with 11 samples from Juvfonne in 2011 by comparing for the first time ${ }^{14} \mathrm{C}$ ages determined from carbonaceous particles with ${ }^{14} \mathrm{C}$ ages conventionally obtained from organic remains found in the ice (Zapf et al., 2013). The 2011 samples are JUV1 and JUV2, adjacent to the dated organic-rich layers in the 2010 tunnel, and a surface sample JUV3 (Table 2). In summer 2015 five samples of clear ice were collected adjacent to the plant fragment layer located just above the bed in the tunnel excavated in 2012 (JUV0, Table 2). All blocks of ice $(\sim 20 \times 15 \times 10 \mathrm{~cm})$ were extracted with a pre-cleaned chainsaw and were subsequently divided into smaller pieces. All ice blocks were transported frozen to the Paul Scherrer Institute (PSI, Switzerland), decontaminated in a cold room by removing the outer layer $(0.3 \mathrm{~mm})$ with a pre-cleaned stainless steel band saw and by rinsing the ice samples with ultra-pure water in a class 100 clean room (Jenk et al., 2007).

Insoluble carbonaceous particles were filtered onto preheated quartz fibre filters (Pallflex Tissuquartz, 2500QAOUP) and combusted with a thermo-optical organic carbonelemental carbon (OC-EC) analyser (Model4L, Sunset Laboratory Inc., USA), using a well-established protocol (Swiss_4S) for OC-EC separation (Zhang et al., 2012). Analyses of ${ }^{14} \mathrm{C}$ were conducted using the $200 \mathrm{kV}$ compact radiocarbon system "MICADAS" at the University of Bern (LARA laboratory), equipped with a gas ion source coupled to the Sunset instrument, allowing direct measurement of ${ }^{14} \mathrm{C}$ in $\mathrm{CO}_{2}$ of 3-100 $\mu \mathrm{g} \mathrm{C}$, with an uncertainty level as low as 
Table 2. AMS radiocarbon dates from the ice tunnels (clear ice samples and organic remains) and ice samples from the ice patch surface. Ice samples collected as blocks and subdivided in several sub-samples. Therefore, an average value is shown for every block (JUV1, JUV2 and JUV3), except for JUV0 because JUV0_1 and JUV0_2 were taken adjacent to the plant fragment layer, dated 6600 cal BP (Poz-56955), while samples from JUV0_3 to JUV0_8 were collected at the bottom of the wall, a few centimetres below the plant fragment layer. Thus, JUV0_A is the yielded average of JUV0_1 and JUV0_2, while the other six samples were averaged as JUV0_B. Calibrated ages (cal BP) denote the $1 \sigma$ range.

\begin{tabular}{|c|c|c|c|c|c|}
\hline Sample ID & AMS Lab. No. & Type of material & $\begin{array}{r}{ }^{14} \mathrm{C} \text { age } \\
\text { (BP) }\end{array}$ & $\begin{array}{l}\text { Cal age } \\
\text { (cal BP) }\end{array}$ & $\begin{array}{r}\text { Median probability } \\
(\text { (cal BP) }\end{array}$ \\
\hline JUV3_1 (tunnel 2010) & ETH 42845.1.1 & Surface ice & $-939 \pm 93$ & & \\
\hline JUV3_2 (tunnel 2010) & ETH 42847.1.1 & Surface ice & $-722 \pm 110$ & & \\
\hline JUV3_3 (tunnel 2010) & ETH 42849.1 .1 & Surface ice & $-1158 \pm 104$ & & \\
\hline JUV3_4 (tunnel 2010) & ETH 43446.1 .1 & Surface ice & $-1220 \pm 117$ & & \\
\hline JUV3 (tunnel 2010) & & Surface ice & $-1010 \pm 120$ & $(-46$ to -7$)$ & -43 \\
\hline Poz-37877 (tunnel 2010) & Poz-37877 & Organic remains & $1095 \pm 30$ & $963-1052$ & 1001 \\
\hline JUV2_1 (tunnel 2010) & ETH 43443.1.1 & Ice & $1018 \pm 210$ & & \\
\hline JUV2_2 (tunnel 2010) & ETH 43445.1 .1 & Ice & $1873 \pm 669$ & & \\
\hline JUV2_3 (tunnel 2010) & ETH 43559.1.1 & Ice & $1119 \pm 323$ & & \\
\hline JUV2_4 (tunnel 2010) & ЕTH 45109.1.1 & Ice & $1128 \pm 287$ & & \\
\hline JUV2 (tunnel 2010) & & Ice & $1277 \pm 207$ & $965-1368$ & 1190 \\
\hline Poz-37879 (tunnel 2010) & Poz-37879 & Organic remains & $1420 \pm 30$ & $1300-1338$ & 1322 \\
\hline Poz-39788 (tunnel 2010) & Poz-39788 & Reindeer dung & $1480 \pm 30$ & $1335-1395$ & 1363 \\
\hline Poz-37878 (tunnel 2010) & Poz-37878 & Organic remains & $1535 \pm 30$ & $1380-1518$ & 1438 \\
\hline Poz-56952 (tunnel 2012) & Poz-56952 & Organic remains & $2027 \pm 31$ & 1929-2002 & 1974 \\
\hline JUV1_3 (tunnel 2010) & ETH 43555.1.1 & Ice & $2141 \pm 304$ & & \\
\hline JUV1_4 (tunnel 2010) & ETH 43557.1.1 & Ice & $2650 \pm 715$ & & \\
\hline JUV1 (tunnel 2010) & & Ice & $2386 \pm 314$ & $2011-2783$ & 2450 \\
\hline Poz-36460(tunnel 2010) & Poz-36460 & Organic remains & $2958 \pm 35$ & $3065-3174$ & 3118 \\
\hline Poz-56953 (tunnel 2012) & Poz-56953 & Organic remains & $3490 \pm 35$ & $3716-3828$ & 3764 \\
\hline Poz-56954 (tunnel 2012) & Poz-56954 & Organic remains & $4595 \pm 35$ & $5148-5445$ & 5316 \\
\hline Tra-4427 (tunnel 2012) & Tra-4427 & Organic remains & $5044 \pm 100$ & $5664-5904$ & 5791 \\
\hline Poz-56955 (tunnel 2012) & Poz-56955 & Organic remains & $5796 \pm 33$ & $6561-6656$ & 6597 \\
\hline JUV0_1 (tunnel 2010) & BE 4184.1.1 & Ice & $5913 \pm 252$ & & \\
\hline JUV0_2 (tunnel 2010) & BE 4380.1.1 & Ice & $6290 \pm 141$ & & \\
\hline JUV0_A (tunnel 2012) & & Ice & $6099 \pm 240$ & $6720-7256$ & 6970 \\
\hline JUV0_3 (tunnel 2012) & BE 4185.1.1 & Ice & $6504 \pm 217$ & & \\
\hline JUV0_4 (tunnel 2012) & BE 4381.1.1 & Ice & $6559 \pm 127$ & & \\
\hline JUV0_5 (tunnel 2012) & BE 4186.1.1 & Ice & $7301 \pm 239$ & & \\
\hline JUV0_6 (tunnel 2012) & BE 4382.1.1 & Ice & $6632 \pm 202$ & & \\
\hline JUV0_7 (tunnel 2012) & BE 4187.1.1 & Ice & $7281 \pm 219$ & & \\
\hline JUV0_8 (tunnel 2012) & BE 4383.1.1 & Ice & $6397 \pm 232$ & & \\
\hline JUV0_B (tunnel 2012) & & Ice & $6761 \pm 168$ & $7476-7785$ & 7632 \\
\hline
\end{tabular}

$1 \%$ (Ruff et al., 2010). Dates are given in calibrated ages BP $(\mathrm{BP}=1950 \mathrm{CE})$ including 1 sigma errors $(\sigma)$.

\section{Results}

\subsection{Ice thickness and ice layering}

The bed reflection was clearly seen in the radar plots (see example in Fig. 4). In addition, the ice layering was detected on most of the plots, probably due to density differences in the ice layers (air bubbles) (Hamran et al., 2009) or organic layers. Georadar soundings from 2009 revealed a maximum ice thickness of 17-19 m (Ødegård et al., 2011). The near- surface reflection horizons are nearly parallel to the present surface. At depth, curved reflection horizons are observed. In the tunnels the curved layers can be directly observed, forming a distinct angular discontinuity with the surface-parallel ice layers (Fig. 5). The surface-parallel layers have melted away since 2009 in the central and southern parts of the ice patch (Fig. 6). The DTM obtained from laser scanning combined with the bottom topography from the georadar gave a volume of $710000 \mathrm{~m}^{3}$ in late August 2011 (mean thickness $5.6 \mathrm{~m}$ ). The surface of Juvfonne in September 2011 was the reference surface for the depth map (Fig. 3b). The maximum depth was $16 \mathrm{~m}$ close to the inner part of ice tunnel excavated in 2012. In this area the surface slope is about $18^{\circ}$. 


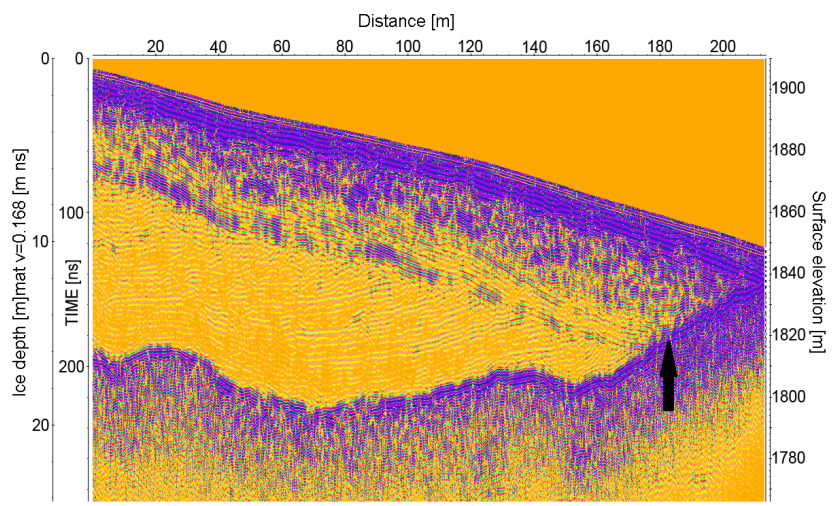

Figure 4. Example of $250 \mathrm{MHz}$ georadar profile. The position of the track is shown in Fig. 3b. The arrow shows the approximate minimum front position in September 2014.

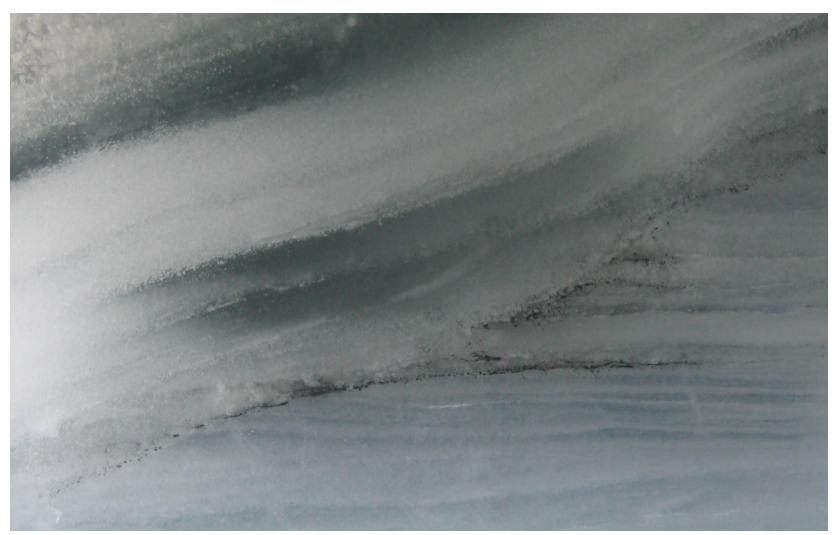

Figure 5. Photo of angular discontinuity at the wall of the 2010 ice tunnel, as also observed from the georadar data (Fig. 4). The upper layering is parallel to the surface of Juvfonne. Radiocarbon dating of the upper part showed modern age. Width of the picture is approximately $0.4 \mathrm{~m}$.

\subsection{Mass balance, front changes and areal extent}

Only one of the mass balance stakes (J2) existed continuously from spring 2010 to spring 2015 (Figs. 7 and 8). Stake $\mathrm{J} 2$ is in the central part of the ice patch (Fig. 3a).

Snow sounding measurements $(N=232)$ range from 0.6 to $4.8 \mathrm{~m}$ over the period 2010-2015. Mean snow depth is $2.6 \mathrm{~m}$ ( $1.2 \mathrm{~m}$ w.e.). Some years show a pattern where most snow accumulates on the leeward side of the prevailing wind the previous winter, but this is not consistent. Interannual variation accounts for $66 \%$. The accumulation was further investigated by analysing the deviation from mean each year. This dataset contains a significant trend with increased accumulation towards the front (Fig. 3c). The difference between the upper central area and the front is $0.2 \mathrm{~m}$ w.e. (Fig. 3c), which corresponds to an approx. $20 \%$ increase in accumulation.

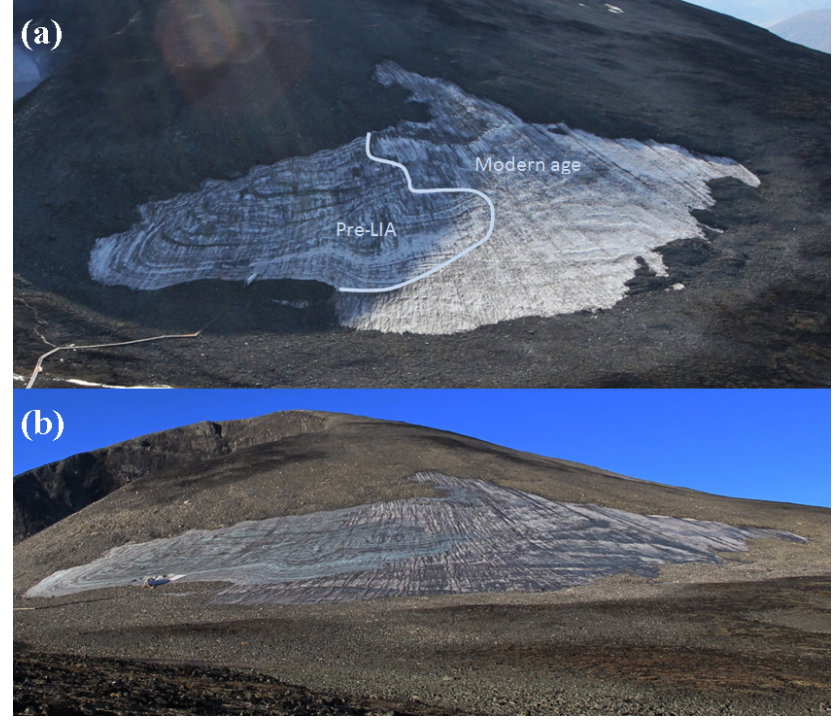

Figure 6. Photos of Juvfonne on 17 September 2014 (a) and 10 September 2014 (b) showing the pre-LIA surface exposed in the central and southern parts of the ice patch (left side). The area on Juvfonne in the north-west (right side) is interpreted to be ice of modern age. The entrance of the ice tunnel sits on a small ridge that might be ice cored (left side, lower image). The collapsed 2010 tunnel is to the left of the entrance. Photo: Glacier Archaeology Program, Oppland County Council (upper) and L. M. Andreassen (lower).
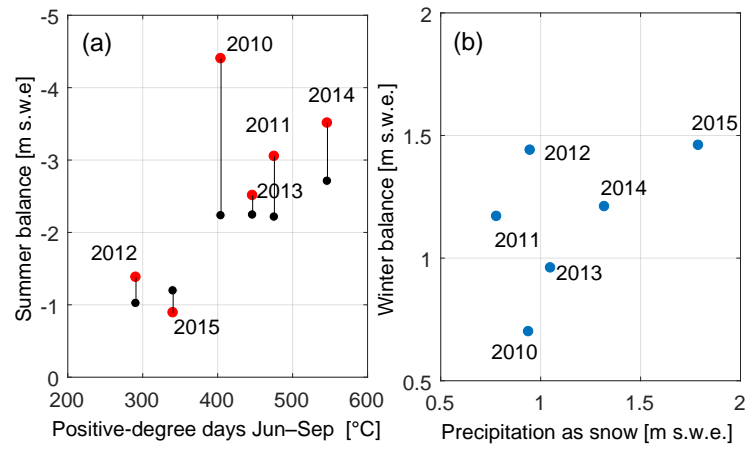

Figure 7. Summer (a) and winter (b) balance plotted against summer temperature (positive-degree days) and estimated precipitation as snow respectively. For the summer balance, the black markers are calculated melt using a degree-day model with typical values calibrated from nearby glaciers $\left(3.5 \mathrm{~mm}^{\circ} \mathrm{C}^{-1} \mathrm{day}^{-1}\right.$ for snow and $7.5 \mathrm{~mm}^{\circ} \mathrm{C}^{-1} \mathrm{day}^{-1}$ for ice). Winter precipitation is obtained from seNorge (Engeset et al., 2004).

The total mass loss is measured to $10 \mathrm{~m}$ of ice at the site of the thermistor measurements (Fig. 3a). The $10 \mathrm{~m}$ thermistor cable installed on 29 October 2009 melted out in mid-September 2014. The total mass loss at stake J2 was $10.5 \mathrm{~m}$ w.e. during the same period. Elevation changes from September 2011 to September 2014 are shown in Fig. 3d. These results are based on the laser scanning in 2011 and dif- 


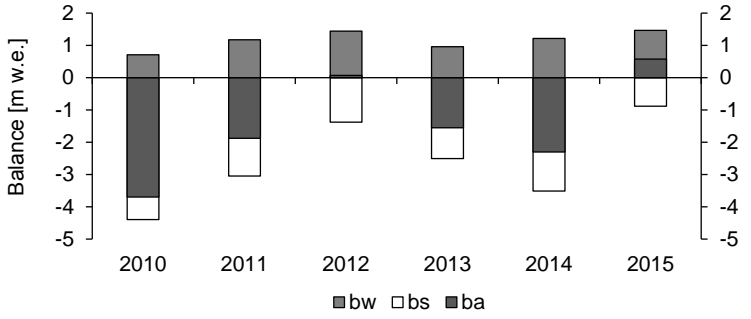

Figure 8. Mass balance measurements at stake J2 on Juvfonne: bw - balance winter, bs - balance summer, ba - annual (net) balance (Fig. 3a for position of stake).

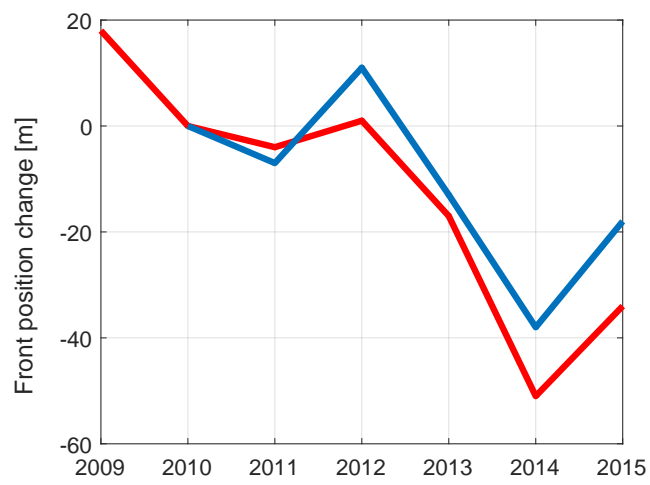

Figure 9. Front position of Juvfonne measured at two locations relative to the 2010 front. Minima are observed in 2011 and 2014. The front retreat 2009-2014 was measured to $69 \mathrm{~m}$. For position of measurements, see Fig. 3a. Red - JF1, blue - JF2.

ferential GNSS tracking in 2014. The measurements show a highly significant asymmetric pattern with close-to-zero surface elevation changes in the western part and surface lowering of 3-5 $\mathrm{m}$ in the eastern and central parts of the ice patch. This strong gradient is measured over a distance of just $200 \mathrm{~m}$ at approximately the same altitude. The part with the most negative change has more than average accumulation.

Front change measurements started in 2009 at JF1 and in 2010 at JF2 (Fig. 9). The measurements revealed that Juvfonne retreated in all years except in 2012 and 2015 where the ice patch increased its size due to excessive snow that formed a thin ice and snow layer around the margin. The total retreat 2009-2014 is $-52 \mathrm{~m}$ measured from JF1, and during 2010-2014 the mean change is $44 \mathrm{~m}(-51 \mathrm{~m}$ from JF1 and $-38 \mathrm{~m}$ from JF2).

The annual extent measurements (2010-2015) show area fluctuations of the margin, varying from $0.101 \mathrm{~km}^{2}$ (9 September 2014) to a maximum of $0.186 \mathrm{~km}^{2}$ on 11 September 2015 (Table 1). The extent measurements show that the ice patch shrinks and grows along the whole margin. Furthermore, field observations show that the ice is very thin along the margins. In 2015 , seasonal snow covered the entire margin, and the measured area of $0.186 \mathrm{~km}^{2}$ is thus
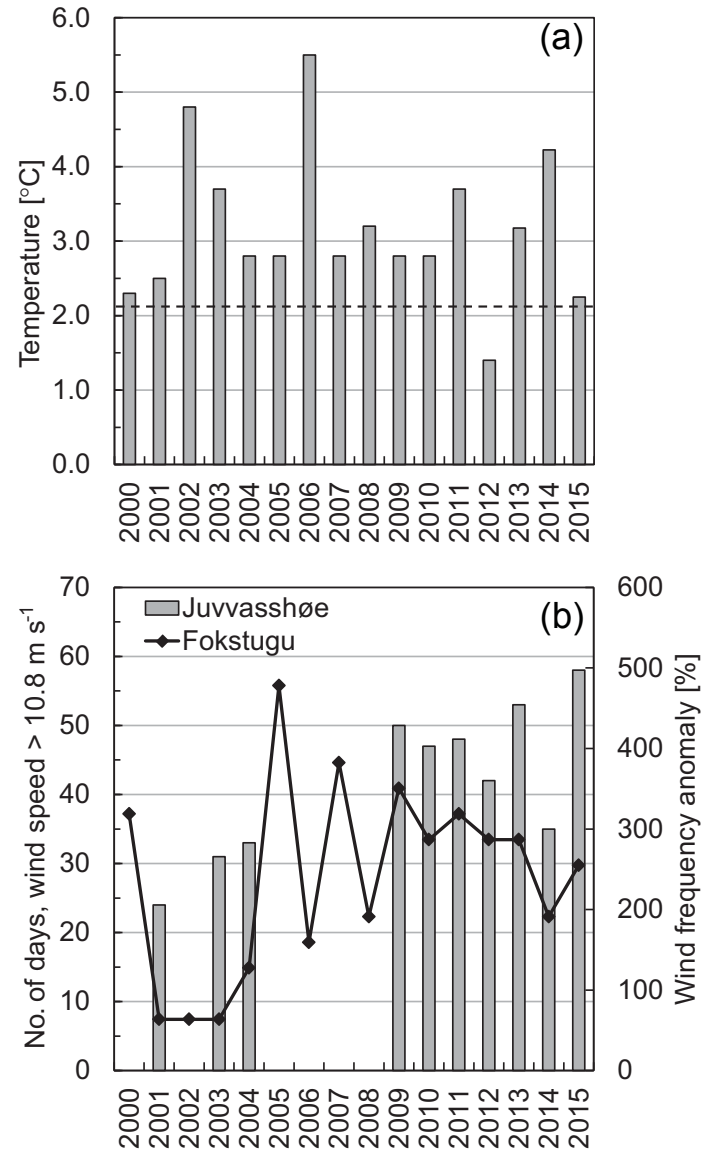

Figure 10. Meteorological data from the station at Juvvasshøe (750 $\mathrm{m}$ from the front of Juvfonne) and Fokstugu $70 \mathrm{~km} \mathrm{NE} \mathrm{(a)}$ Juvvasshøe June-September mean air temperature. The black dotted line denotes the 1971-2000 mean, obtained from the interpolated seNorge dataset (Engeset et al. 2004). (b) Number of days for the period June-September with strong breeze or higher (wind speed above $10.8 \mathrm{~m} \mathrm{~s}^{-1}$ ) at Juvvasshøe (grey bars) and at Fokstugu (black line), the latter shown as anomaly (in \%, right axes) with respect to 1971-2000 mean.

only to be considered a maximum extent, not the actual ice patch area.

\subsection{Climate parameters}

Air temperature and wind speed at Juvvasshøe for the period 2000-2015 are outlined in Fig. 10a-b over the ablation season (June-September). The mean June-September air temperature in this period is $3.2^{\circ} \mathrm{C}\left(1.0^{\circ} \mathrm{C}\right.$ above the $1971-2000$ mean). Air temperatures, near-ground surface temperatures and frequency of days with daily mean air temperature above $0{ }^{\circ} \mathrm{C}$ (the two latter are not shown in Fig. 10) are high in summers 2002, 2003, 2006, 2011 and 2014, and especially 2006. Observations from nearby weather stations with long climate series reported record-breaking temperatures in late summer and autumn 2006. In the investigation period 2009-2015 the 


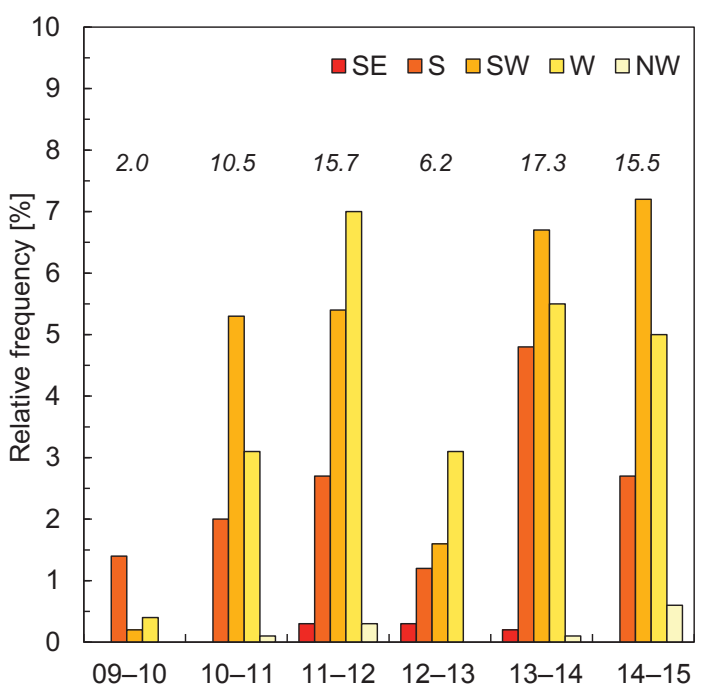

Figure 11. Relative frequency (as percentage of all hourly observations) of strong gale or more ( $\geq 20.8 \mathrm{~m} \mathrm{~s}^{-1}$ ) at Juvvasshøe during winter (Oct-Apr) 2009-2015 for the wind sectors SE to NW. The values inserted show the total frequency of strong gale or more.

coldest summer was 2012 , which was the only summer below the 1971-2000 mean (Fig. 10).

Due to the sheltered setting of Juvfonne compared to the meteorological stations, strong breeze (wind speed above $10.8 \mathrm{~m} \mathrm{~s}^{-1}$ ) was used as a lower limit to obtain sufficiently high wind speeds for effective and enhanced turbulent fluxes at Juvfonne. In general there was a high frequency (3558 days per season) of strong breeze during the period 20092015 (Fig. 10b). Comparing wind data from the AWS at Fokstugu indicates 2 to 3 times more frequent strong wind mean during the investigation period than 1971-2000. Observed incoming short- and long-wave radiation from Juvvasshøe (not shown) show no clear patterns related to single summers, but 2011 stands out as the summer with the greatest incoming long-wave radiation.

For snow accumulation or abrasion on ice patches, wind speed and wind direction is crucial (Dadic et al., 2010; Lehning et al., 2008). There are great variations from year to year in respect to frequency of strong gale and wind direction. During the two stormiest winters 2011-2012 and 2013-2014, the frequency of strong gale was 15.7 and $17.3 \%$ respectively (Fig. 11).

\subsection{Snow measurements and modelling}

The automatic snow depth observations in front of Juvfonne show great hourly to daily variability and there is a distinctly different pattern of snow accumulation between the four winter seasons (Fig. 12). The greatest increase in snow depth during early and mid-winter in all years is related to storm events. This is also the case for strong snow depth decrease events (mainly due to wind scouring). Comparing
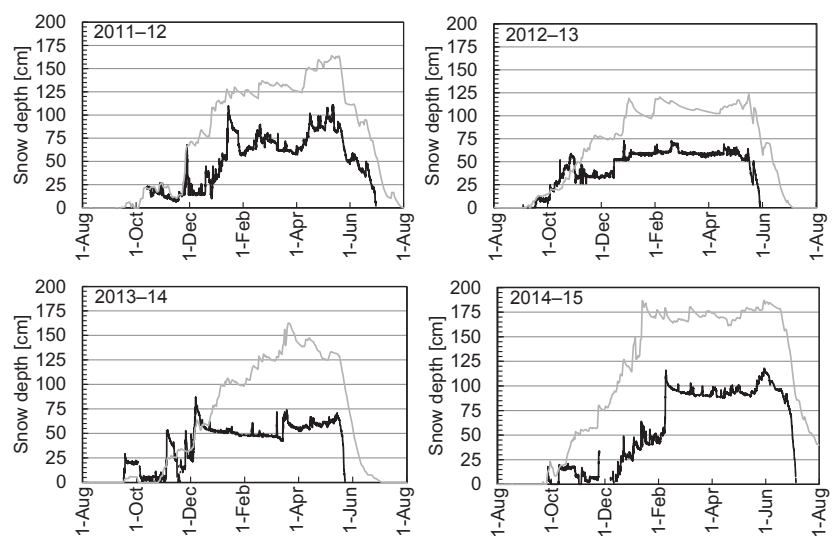

Figure 12. Hourly snow depth measurements (black lines) from the station $95 \mathrm{~m}$ from the front of Juvfonne (see Fig. 3a for position). Grey lines show modelled daily snow depth from seNorge (Engeset et al. 2004).

the observed and estimated snow depths (which do not take into account redistribution of snow by wind), it is clear that much of the accumulation is not correlated with precipitation (Fig. 12). The snow depth for Juvfonne was obtained from a precipitation and degree-day model operating on $1 \times 1 \mathrm{~km}^{2}$ developed for a web-based system (http://senorge.no/) for producing daily snow maps for Norway (Engeset et al., 2004; Saloranta, 2012). A similar poor correlation $\left(r^{2}=0.24\right)$ is also found for very small glaciers in the Alps (Huss and Fischer, 2016).

The observed melt in central parts (J2) was compared with a degree-day model using typical values calculated from nearby glaciers (Fig. 7a) (Laumann and Reeh, 1993). This modelling shows a quite good fit, except for the 2010 season. In this season, the summer balance was about twice the outcome of the degree-day model.

\subsection{Temperature of ice and permafrost}

Temperature measurements in Juvfonne reveal $10 \mathrm{~m}$ depth ice temperature in the range of -2 to $-4{ }^{\circ} \mathrm{C}$ (Fig. 13). The ice and snow temperature results show that the Juvfonne ice patch is cold-based and underlain by permafrost. The measurements at 5-10 $\mathrm{m}$ depth in the ice are similar to the measurements in the nearby permafrost borehole at Juvvasshøe (Fig. 13). In spring, the meltwater percolates and refreezes in the snowpack until the snow is isothermal at a temperature close to $0^{\circ} \mathrm{C}$ (Fig. 14). There is cold ice below the level of meltwater percolation, which means that there is a heat flow into the ice that gradually decreases during the melt season. Because of this heat flow, superimposed ice, generally less than $0.1 \mathrm{~m}_{\text {year }}{ }^{-1}$, forms at the level of impermeable ice. 


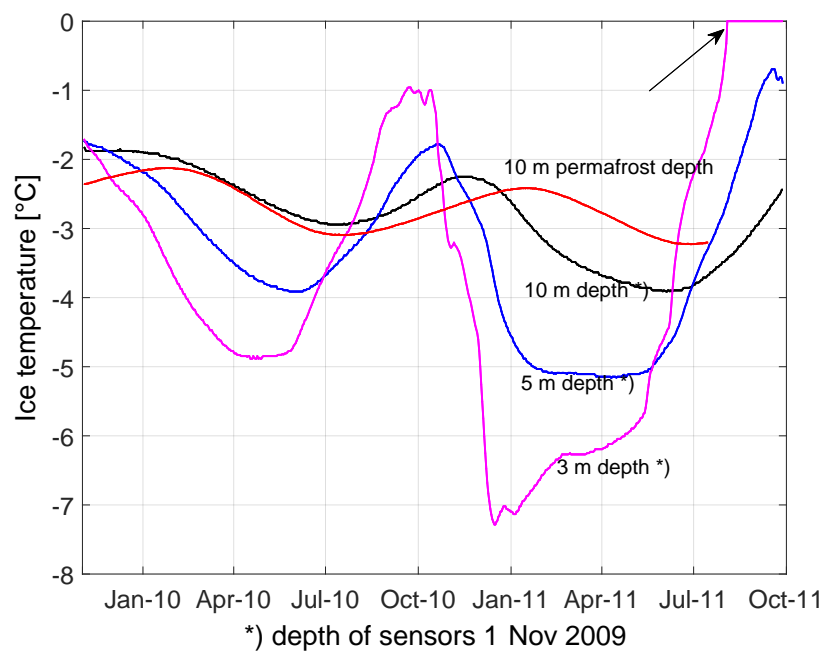

Figure 13. Temperature for November 2009-September 2011 in a $10 \mathrm{~m}$ deep borehole in the Juvfonne ice patch (see Fig. 3a for position). The red line is the temperature at $10 \mathrm{~m}$ depth in the $\mathrm{P} 31$ permafrost borehole $750 \mathrm{~m}$ north from the ice patch (see Fig. 2 for location). Arrow points to the time when the sensor placed at $3 \mathrm{~m}$ depth in autumn 2009 melted out. The entire thermistor string melted out in mid-September 2014.

\subsection{Radiocarbon dating}

The AMS radiocarbon dating obtained from organic-rich layers and from carbonaceous aerosols embedded in clear ice in the Juvfonne ice patch shows ages spanning from modern at the surface to ca. 7600 cal years BP at the bottom (clear ice below the basal organic-rich layer), thus showing that Juvfonne has existed continuously during the last $\sim 7500$ years. So far, the basal ice in Juvfonne is the oldest dated ice in mainland Norway (Table 2).

In the tunnel opened in 2010 the AMS radiocarbon dating of organic matter embedded in the ice shows modern age in the top layer at the entrance and ages ranging from 30653174 to $963-1052$ cal years BP inside the tunnel. These results were previously published in Nesje et al. (2012) and recalibrated for this study (Table 2 and Fig. 15).

In the tunnel opened in 2012 the AMS radiocarbon dating of five organic layers embedded in the ice about $70 \mathrm{~m}$ from the margin of the ice patch, yielded dates in chronological order from the base upwards, ranging from 65616656 cal years BP at the base to 1929-2002 cal years BP in the ceiling of the ice tunnel, approximately $2.8 \mathrm{~m}$ above the tunnel floor. The organic debris that yielded the oldest age was collected from the innermost part of the ice tunnel, about $0.4 \mathrm{~m}$ above the bed. The layer where the sample was retrieved could be followed close to the bed in the inner parts of the tunnel. The carbon dates on carbonaceous aerosols were sampled at the same location to the side and below the plant fragment layer. The oldest dating is $7476-7785$ cal years BP.

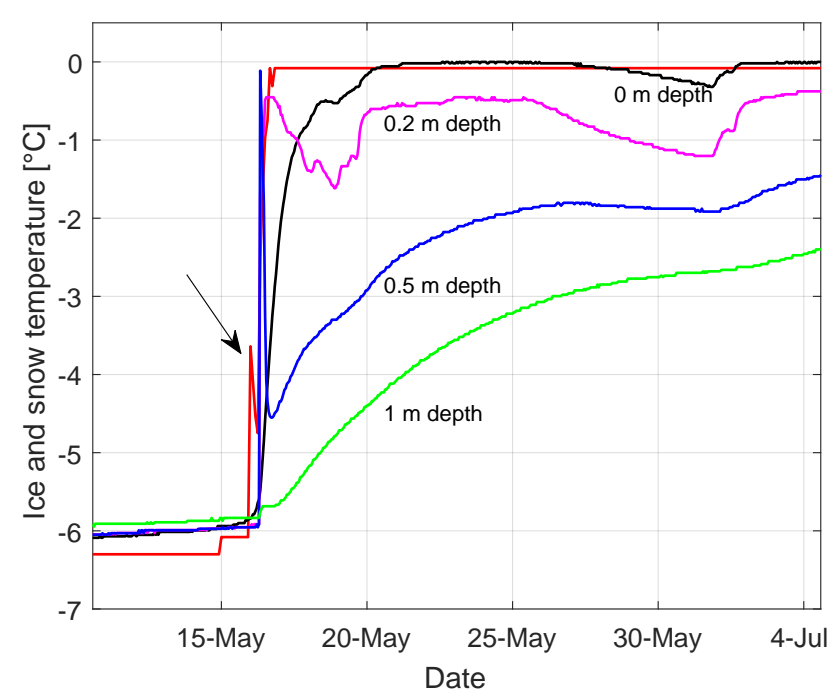

Figure 14. Plot of temperature measurements in ice and snow at the onset of thaw in May 2010 (position at the thermistor shown in Fig. 3a). The depth reference is the ice surface the previous autumn. The red line is the snow temperature $0.25 \mathrm{~m}$ from the base of the snow cover. The arrow points to the first signal of surface meltwater refreezing close to the base of the snow cover.

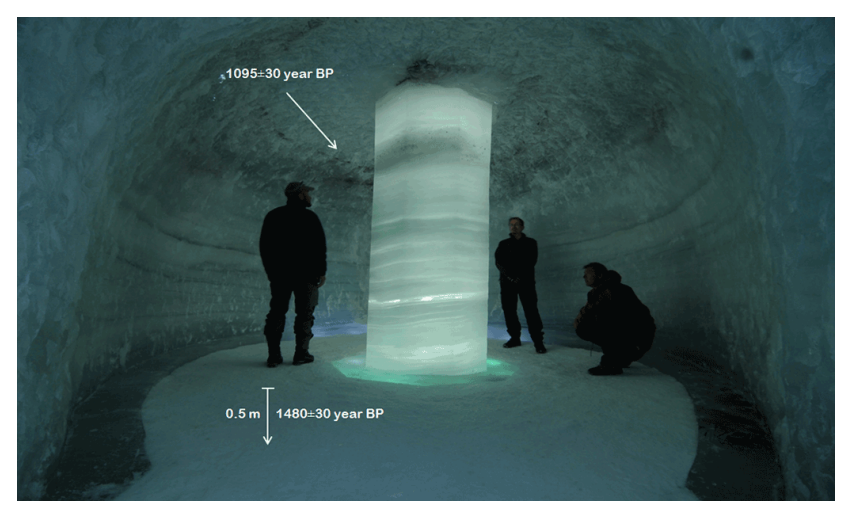

Figure 15. Photo from the old ice tunnel excavated in 2010 showing the layering in the ice and position of two samples for radiocarbon dating. Photo: Klimapark2469 AS.

The position of the sample site in the 2012 tunnel is marked in Fig. 3a.

In autumn 2014, two in situ Polytrichum moss mats melted out along the margin of Juvfonne south of the ice tunnel excavated in 2010. AMS radiocarbon dates of the two moss mats indicate that the moss was killed by the expanding margin of the ice patch about 2000 years ago (1951-1896 cal years BP Poz-66166 and 1945-1882 cal years BP - Poz-66167). Thus, the minimum extent of the south-eastern part of the ice patch observed in September 2014 is most likely the smallest in 2000 years.

With the exception of one identified outlier, the results obtained from dating of carbonaceous aerosol particles in the 


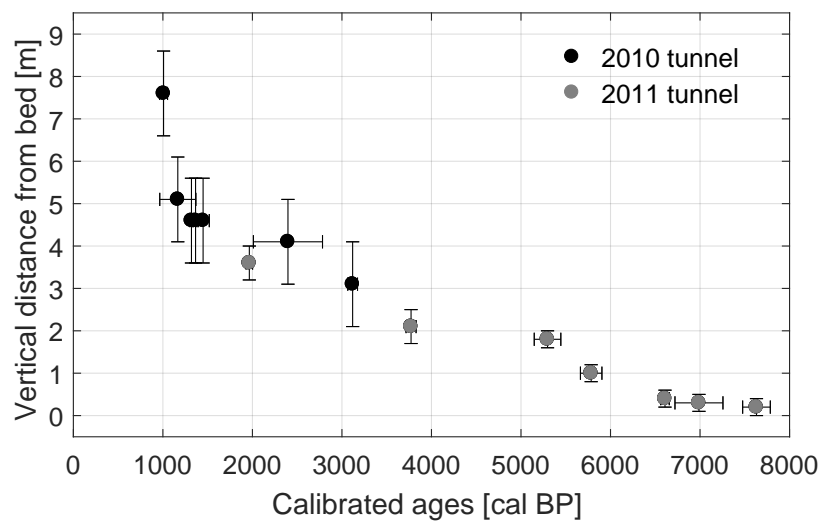

Figure 16. Plot of the samples in Table 2 except samples with modern age. In the inner parts of the 2012 tunnel the bed is partly exposed, which gives good distance to bed estimates. In the 2010 tunnel, the distance estimates depend on the radar data (the old tunnel partly melted out). The horizontal distance between the samples is up to $50 \mathrm{~m}$.

ice could reproduce the expected ages very well (Zapf et al., 2013). This gives confidence that the age of organic debris in the ice is similar to the surrounding ice. In Fig. 16 radiocarbon datings from both ice tunnels are plotted according to vertical distance from bed.

\section{Discussion}

The discussion focuses on the value of this research in the context of the long-term objective to develop models of mass balance and thermal regime on a Holocene timescale at ice patches and surrounding terrain.

The discussion is organized in four sections: (1) the mass balance, (2) thermal regime, (3) ice layering and deformation on Holocene timescale, and (4) the environmental processes relevant to artefact displacement and preservation.

\subsection{The mass balance}

Perennial ice patches are, due to their existence, located at sites with close to long-term zero mass balance. The interannual variability in summer and winter balance could be considerable, but the long-term changes in mass must be close to zero as long as they do not disappear or develop into a glacier. The 6-year record of mass balance gives some insight into the spatial and temporal variability of the mass balance.

The snow accumulation during the 6-year period (20102015) shows increased accumulation towards the front of the ice patch. This is probably a response to increased melt, which will increase the snow accumulation at the leeward side of prevailing westerly winds.

Along the outer rim of Juvfonne, the surface elevation changes (negative mass balance) vary between less than $1 \mathrm{~m}$ and nearly $5 \mathrm{~m}$ within a $200 \mathrm{~m}$ distance at the same altitude over a period of 3 years (Fig. 3d). Field data are consistent with the interpretation of increased melting due to sensible and latent heat fluxes. Micrometeorological investigations by Mott et al. (2011) of processes driving snow ablation in an alpine catchment show that advection of sensible heat causes locally increased ablation rates at the upwind edges of snow patches.

The 2010 anomaly in the summer balance (Fig. 7a) is most likely related to increased melt during periods with strong south and south-easterly winds (unsheltered direction for Juvfonne), combined with relatively high air temperatures and high relative humidity, causing enhanced turbulent fluxes. Extreme melt was observed in early to midAugust. The warmest 10-day period in 2010 was 8-18 August. Median wind speed was $3.4 \mathrm{~m} \mathrm{~s}^{-1}$ from the SE and humidity was $79.5 \%$ at the meteorological station $750 \mathrm{~m}$ from the ice patch. This 2010 anomaly is probably the reason for the asymmetric net balance of Juvfonne (Fig. 6). Exceptionally large melt episodes have been reported from the Central Cascade Mountains of Oregon, where snow melt was enhanced by strong wind, high air temperature and high humidity (Marks et al., 1998). At higher unsheltered sites, 60$90 \%$ of the energy for snowmelt came from sensible and latent heat exchanges, while it was only about $35 \%$ at more sheltered sites. Recently, similar extreme melt events were reported from the southern and western parts of the Greenland ice sheet in July 2012, where non-radiative energy fluxes dominated the ablation area surface energy budget during multi-day episodes (Fausto et al., 2016).

The snow recording from the station in front of Juvfonne ( $95 \mathrm{~m}$ from the front) clearly illustrates the complexity of snow accumulation in this environment. In front of Juvfonne, abrupt changes in snow depth within hours dominate the series, causing great day-to-day variability. These changes seem to be mainly driven by wind speed and wind direction. Single storm events with westerly winds could account for almost $50 \%$ of the winter accumulation in less than $24 \mathrm{~h}$, like the storm on 7-8 February 2015 (Fig. 12, 2014-2015). Spring snow accumulation with insignificant wind drift could also influence mass balance, like the period from early April to mid-May 2012, when more than $40 \mathrm{~cm}$ of snow accumulated (Fig. 12, 2011-2012).

\subsection{Ground and ice thermal regime}

The temperature measurements at Juvfonne show that there is sufficient meltwater to bring the permeable snowpack to an isothermal condition within a few weeks in early summer (Fig. 13). Below the seasonal snowpack, the ice remains cold during the summer, with temperatures in the range of -2 to $-4{ }^{\circ} \mathrm{C}$ at $5-10 \mathrm{~m}$ depth (Fig. 13). In Norway most glaciers are considered temperate, although measurements are available for only a few glaciers (Andreassen and Winsvold, 2012). Recent observations from nearby glaciers 
in Jotunheimen, reveal that at the lower parts of Storbreen the winter cold wave was removed during summer, but remained at Hellstugubreen and Gråsubreen (Sørdal, 2013; Tachon, 2015). The temperatures measured close to the equilibrium line at Hellstugubreen $\left(-1^{\circ} \mathrm{C}\right)$ and Gråsubreen $\left(-2^{\circ} \mathrm{C}\right)$ were warmer than the temperature measured at similar depths at Juvfonne $\left(-3^{\circ} \mathrm{C}\right)$.

Juvfonne consists of cold ice surrounded by permafrost terrain (Fig. 13). Perennial ice patches can be used as indicators of local (mountain) permafrost conditions (Imhof, 1996; Kneisel, 1998). The physical background is that their ice cannot warm above $0^{\circ} \mathrm{C}$ in summer but cool down far below $0{ }^{\circ} \mathrm{C}$ during the cold season. Based on this argument, there is good reason to suggest that long-term perennial ice patches like Juvfonne indicate permafrost directly beneath them. Holocene permafrost modelling (Lilleøren et al., 2012) suggests that permafrost survived the highest areas of the Scandinavian mountains during the Holocene thermal maximum (HTM), and thus permafrost ice could be of Pleistocene age. Radiocarbon dates from Juvfonne show that the deepest central part of the ice patch contains carbonaceous particles embedded in the ice 7476-7785 cal years BP (JUV0_B, Table 2). This is a strong indication that Juvfonne has existed continuously since mid-Holocene, and the dating of the ice could offer testing data for Holocene permafrost models. Juvfonne could contain older ice, and it is most likely that ice patches at higher elevation contain older ice.

\subsection{Ice layering and deformation on a Holocene timescale}

The observed ice layers almost certainly represent surfaces of isochronic deposition. Within both ice tunnels in Juvfonne there are several organic and/or debris layers of uncertain origin. From the appearance of these layers, it is probably windor water-transported material or reindeer droppings. The organic layers are horizontally continuous over a few metres. There is reasonable correlation between the age of the clear ice and the age of the organic layers (Zapf et al., 2013). Contamination is not likely in the clear ice samples, which gives confidence in the dating of the ice stratigraphy. This is not necessarily the case at other ice patches, where surface processes or microbial activity may contaminate organic material exposed at the surface.

The ice deformation on a Holocene timescale is difficult to calculate based on the available data. In the central parts of the ice patch, an estimate of maximum basal shear stress is in the range of $30-40 \mathrm{kPa}$ (surface slope $17^{\circ}$, depth $12-16 \mathrm{~m}$, laminar flow). Adding $5 \mathrm{~m}$ to the depth will increase the basal shear stress to $45-55 \mathrm{kPa}$ for the central part. The latter is probably close to the range for the last decades. Calculation of deformation based on a Glen-type flow law will be highly sensitive to the chosen stress exponent (Glen, 1955). Using a softness parameter $A=2.4 \times 10^{-15} \mathrm{~s}^{-1} \mathrm{kPa}^{-3}$ based on an ice temperature of $-2{ }^{\circ} \mathrm{C}$ from Table 5.2 in Paterson (1994)

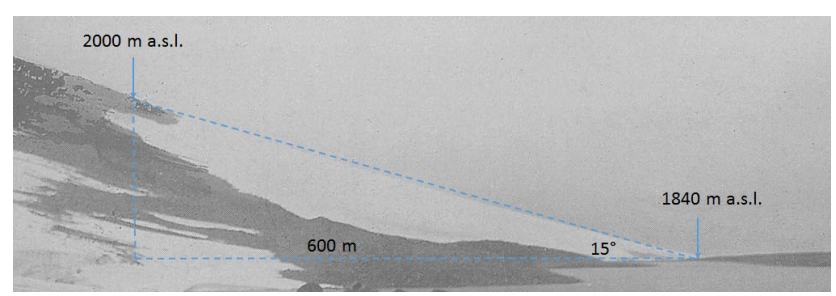

Figure 17. Picture taken from Vesljuvbrea towards the NNW showing Juvfonne from around 1900. The surface slope of Juvfonne is approximately $15^{\circ}$. Height and length estimate from map based on position in the picture. The upper and northern part of Juvfonne cannot be seen in the picture.

and a stress exponent of $n=2$ (Duval et al., 2000) gives a surface velocity of $2.3 \mathrm{~m} 1000$ years $^{-1}$ (surface slope $17^{\circ}$, depth $19 \mathrm{~m}$, laminar flow). A likely situation for the LIA (surface slope $15^{\circ}$, depth $45-60 \mathrm{~m}$ ) gives an estimate of $25-$ $60 \mathrm{~m} 1000$ years $^{-1}$, assuming a cold-based glacier (Fig. 17). These calculations have high uncertainty but suggest that a cumulative deformation of ice over millennia could explain the observed curved layering in the basal layer of the ice patch (Fig. 4). The possibility of cumulative ice deformation on a timescale of several millennia makes it difficult to relate the present thickness and slope of these layers to previous thicknesses of the ice patch.

\subsection{Artefact displacement and preservation}

From a cultural management perspective, there is particular interest in developing methods to identify sites of interest (Rogers et al., 2014) and a better understanding of the environmental threats (Callanan, 2015). The environmental threats are mainly related to subaerial exposure of artefacts. Especially leather artefacts, textiles and steering feathers of arrows are exposed to movement and decomposition only a short time after melt-out. Wooden objects are more resistant.

The artefacts found at Juvfonne are in permafrost terrain surrounding the ice patch; most of them are found in the front of the ice patch within a few tens of metres. The wooden artefacts range from 250 to $900 \mathrm{CE}$. Even during the extreme minimum in September 2014 (Fig. 6), there were no observations of artefacts melting out from the ice.

The exposure time to subaerial processes and microbial activity is critical to artefact decomposition. At Juvfonne, there is a gradual increase in the ground exposure time depending on snow accumulation and melt over millennia. The oldest ice found so far is 7476-7785 cal years BP (JUV0_B, Table 2). At the eastern edge, AMS radiocarbon dates show that the moss mats were covered (killed) by the expanding snowfield about 2000 years ago (Table 2, Poz-56952). Lichenometry indicates that the front of Juvfonne extended $\sim 250 \mathrm{~m}$ from its present position during the LIA maximum in the mid-18th century (Nesje et al., 2012). A photo of Juvfonne from around 1900 shows the front close to the expected LIA 
extent (Fig. 17). These results constrain the extent of the ice patch since the mid-Holocene, but temporal and spatial variability need to be considered to assess the actual exposure time of artefacts.

Several radiocarbon dates of the top layer in 2010 (Table 2 and Fig. 4) show modern age. This means that artefacts found outside the 2010 extent were subaerially exposed after the LIA but prior to 2010. Thus, the dating and position of artefacts cannot be used directly to reconstruct previous ice patch extent.

Juvfonne and surrounding terrain is an active environment in terms of geomorphological processes. In particular, during the extreme melting in autumn 2014 several small accumulations of organic material and/or debris occurred at the upper margin of the ice patch. Within a few days, meltwater moved this material to the front of the ice patch. Downslope movement of artefacts by meltwater is certainly possible at Juvfonne. Finds at other ice patches in Jotunheimen support this interpretation, where different pieces of the same artefact were found along the direction of the steepest slope. Textiles and leather objects are more likely transported by wind, and preservation at its original position is less likely. There are no finds of textiles or leather objects at Juvfonne.

\section{Conclusions and future perspectives}

The exploratory analyses of field data from Juvfonne show the geoscience research potential of ice patches in Scandinavia. The results give new insights into their age, internal structure, mass balance and climate sensitivity and have taken the state of knowledge to a level where models can be designed.

These are the main conclusions from the analysis of field data:

- Ice stratigraphic characteristics and radiocarbon dating strongly suggest that the Juvfonne ice patch was small or absent during the Holocene thermal maximum, but it has existed continuously since ca. 7600 cal years BP (the late Mesolithic period) without disappearing. This is the oldest dating of ice in mainland Norway.

- Geophysical investigations show a clear stratification. The observed ice layers almost certainly represent surfaces of isochronic deposition. Several radiocarbon dates of the top layer (parallel to the surface) show modern age. At depth, curved reflection horizons are observed consistent with cumulative ice deformation over millennia.

- A 6-year record of mass balance measurements shows a strongly negative balance. The total mass loss at one site was $10.5 \mathrm{~m}$ w.e. Elevation changes are highly asymmetric over short distances, from close to zero to a surface lowering of several metres. There is a significant increase in snow accumulation towards the front of approx. $20 \%$ compared to the upper central area. The winter balance is poorly correlated with winter precipitation. One single storm event may contribute significantly to the winter balance.

- Temperature measurements of the ice in Juvfonne reveal colder ice than what is found at similar depths close to the equilibrium line of nearby polythermal glaciers. There is sufficient meltwater to bring the permeable snowpack to an isothermal state within a few weeks in early summer. Below the seasonal snowpack, at 5-10 m depth, the ice remains cold, with temperatures between -2 and $-4{ }^{\circ} \mathrm{C}$. The cold ice is surrounded by permafrost terrain that has similar ground temperatures.

- Ice deformation and surface processes (i.e. wind and meltwater) may have caused significant displacement of artefacts from their original position. Since the surface ice shows modern age, artefacts melted out in front of Juvfonne during the last decades must have been subaerially exposed on at least one previous occasion after the LIA.

The radiocarbon datings show that Juvfonne is robust to climate change, even on a Holocene timescale. The datings indicate a slow buildup over a period of 8000 years. The survival of relatively thin ice over a long period is a good documentation of the mass balance feedback mechanisms of ice patches. The datings of moss mats appearing at the southeastern edge of Juvfonne in September 2014 suggest that it was the smallest ice patch in $\sim 2000$ years. These field data constrain the Holocene development of Juvfonne, but care should be taken in the interpretation. Radiocarbon datings of the ice layers only show the timing of minima in volume.

The possibility of cumulative deformation of ice on a Holocene timescale makes it difficult to relate the present thicknesses and slope of these layers to previous thickness of the ice patch. Maximum ice volume was reached during LIA, when Juvfonne probably developed into a cold-based glacier with significant internal deformation.

Perennial ice patches are, due to their existence, areas with close-to-zero long-term mass balance similar to the zone close to the ELA of glaciers. However, there are obvious differences between ice patches and glaciers. The accumulation processes are to a variable degree dependent on surrounding topography and the topography of the ice patch itself. One possible future approach is field observations in combination with simulations of the wind field to obtain the necessary spatial and temporal resolution to model the snow accumulation during storm events.

The wind field with high spatial and temporal resolution is also needed to calculate the turbulent fluxes. The melt anomaly in 2010 was probably related to periods of strong south-easterly winds, high air temperatures and high relative moisture boosting the turbulent fluxes at the upwind edge. 
The time series of mass balance at Juvfonne is too short to study the long-term effect of melt anomalies.

\section{Data availability}

The ice thickness and point mass balance data of Juvfonne were submitted to the World Glacier Monitoring Service (WGMS) to their Glacier Thickness Database (GlaThiDa) and Fluctuations of Glaciers Database (FoG). The snow accumulation data are included in the supplement. Meteorological data for the Juvvasshøe (15270) and Fokstugu (16610) stations are available for free download from the climate database of the Norwegian Meteorological Institute, eKlima (http://eklima.met.no/, Norwegian Meteorological Institute, 2016).

Acknowledgements. We thank the archaeologists Lars Pilø and Espen Finstad for valuable comments and discussions related to artefact displacements and Dag Inge Bakke at Mimisbrunnr Klimapark 2469 for support in the field. Professor Emeritus Wilfried Haeberli and Professor Bernd Etzelmüller gave useful comments on an earlier version of the manuscript and are gratefully acknowledged. We thank the two anonymous reviewers for precise feedback, which greatly improved the paper.

Edited by: S. Gruber

Reviewed by: two anonymous referees

\section{References}

Andreassen, L. M.: Glaciological investigations in Norway in 2010 - Juvfonne, NVE report 3, edited by: Kjølmoen, B., Norwegian Water Resources and Energy Directorate, Oslo, Norway, 54-57, 2011.

Andreassen, L. M. and Winsvold, S. H.: Inventory of Norwegian Glaciers, Norwegian Water Resources and Energy Directorate, Oslo, Norway, 236 pp., 2012.

Andreassen, L. M., Elvehøy, H., Kjøllmoen, B., Engeset, R. V., and Haakensen, N.: Glacier mass-balance and length variations in Norway, Ann. Glaciol., 42, 317-325, 2005.

Andreassen, L. M., Paul, F., Kääb, A., and Hausberg, J. E.: Landsatderived glacier inventory for Jotunheimen, Norway, and deduced glacier changes since the 1930s, The Cryosphere, 2, 131-145, doi:10.5194/tc-2-131-2008, 2008.

Andrews, T. D. and Mackay, G.: The Archaeology and Paleoecology of Alpine Ice Patches: A Global Perspective, Arctic, 65, 4 pp., 2012.

Bakke, J., Dahl, S. O., Paasche, Ø., Riis Simonsen, J., Kvisvik, B., Bakke, K., and Nesje, A.: A complete record of Holocene glacier variability at Austre Okstindbreen, northern Norway: an integratd approach, Quaternary Sci. Rev., 29, 1246-1262, 2010.

Bronk Ramsey, C. and Lee, S.: Recent and Planned Developments of the Program OxCal, Radiocarbon, 55, 720-730, 2013.

Brunswig, R. H.: Risks and Benefits of Global Warming and the Loss of Mountain Glaciers and Ice Patches to Archeological, Pa- leoclimate, and Paleoecology Resources, Ecological Questions, 20, 99-108, 2014.

Callanan, M.: Northern Snow Patch Archaeology, in: A Circumpolar Reappraisal: The Legacy of Gutorm Gjessing (1906-1979), edited by: Westerdahl, C., Arcaeopress, Oxford, 43-54, 2010.

Callanan, M.: Managing the frozen heritage: Some challenges and responses, Quatern. Int., 402, 72-79, 2015.

Ceruti, C.: Human bodies as objects of dedication at Inca mountain shrines, north-western Argentina, World Archaeol., 36, 103-122, 2004.

Curry, A.: Racing the thaw, Science, 346, 157-159, 2014.

Dadic, R., Mott, R., Lehning, M., and Burlando, P.: Wind influenceonsnow depth distribution and accumulation over glaciers, J. Geophys. Res., 115, F01012, doi:10.1029/2009JF001261, 2010.

Dixon, J., Manley, W. E., and Lee, C. M.: The emerging archaeology of glaciers and ice patches, Am. Antiquity, 70, 129-143, 2005.

Dixon, E. J., Callanan, M., Hafner, A., and Hare, G. P.: The Emergence of Glacial Archaelogy, J. Glacial Archaeol., 1, 1-9, 2014.

Duval, P., Arnaud, L., Brissaud, M., Montagnat, M., and de la Chapelle, S.: Deformation and recrystallization processes of ice from polar ice sheets, Ann. Glaciol., 30, 83-87, 2000.

Engeset, R. V., Tveito, O. E., Alfnes, E., Mengistu, Z., Udnæs, H.C., Isaksen, K., and Førland, E. J.: Snow Map System for Norway, XXIII Nordic Hydrological Conference, Tallinn, Estonia, 8-12 August 2004, 48, 112-121, 2004.

Essery, E., Ganger, R., and Pomeroy, J.: Boundary-layer growth and advection of heat over snow and soil patches: modelling and parameterization, Hydrol. Proc., 20, 953-967, 2006.

Eveland, J. W., Gooseff, M. N., Lampkin, D. J., Barrett, J. E., and Takacs-Vesbach, C. D.: Seasonal controls on snow distribution and aerial ablation at the snow-patch and landscape scales, McMurdo Dry Valleys, Antarctica, The Cryosphere, 7, 917-931, doi:10.5194/tc-7-917-2013, 2013.

Farbrot, H., Hipp, T., Etzelmuller, B., Isaken, K., Ødegård, R. S., Schuler, T. V., and Humlum, O.: Air and Ground Temperatures Variations Observed along Elevation and Continentality Gradients in Southern Norway, Permafrost Periglac., 22, 343-360, doi:10.1002/ppp.733, 2011.

Farnell, R., Hare, G. P., Blake, E., Bowyer, V., Schweger, C., Greer, S., and Gotthardt, R.: Multidisciplinary investigations of alpine ice patches in Southwest Yukon, Canada: paleo-environmental and paleobiological investigations, Arctic, 57, 247-259, 2004.

Fausto, R. S., van As, D., Box, J. E., Colgan, W., Langen, P. L., and Mottram, R. H.: The implication of nonradiative energy fluxes dominating Greenland ice sheet exceptional ablation area surface melt in 2012, Geophys. Res. Lett., 43, 2649-2658, 2016.

Finstad, E. and Vedeler, M.: En bronsealdersko fra Jotunheimen, Viking, 71, 61-70, 2008.

Fujita, K., Hiyama, K., Iida, H., and Ageta, Y.: Self-regulated fluctuations in the ablation of a snow patch over four decades, Water Resour. Res., 46, W11541, doi:10.1029/2009WR008383, 2010.

Fukui, K.: Permafrost and surface movement of an active protalus rampart in the Kuranosuke Cirque, the Northern Japanese Alps, Permafrost Conference, Zurich, 21-25 July, 2003.

Fukui, K. and Iida, H.: Flow of the ice body in the Gozenzawa perennial snow patch, the Tateyama Mountains, central Japan, Japan Geoscience Union Meeting 2011, Chiba, Japan, 22-24 May, 2011. 
Gisnås, K., Etzelmuller, B., Farbrot, H., Schuler, T. V., and Westermann, S.: CryoGRID 1.0: Permafrost Distribution in Norway estimated by a Spatial Numerical Model, Permafrost Periglac., 24, 2-19, 2013.

Gisnås, K., Westermann, S., Schuler, T. V., Melvold, K., and Etzelmüller, B.: Small-scale variation of snow in a regional permafrost model, The Cryosphere, 10, 1201-1215, doi:10.5194/tc10-1201-2016, 2016.

Glazirin, G. E., Kodama, Y., and Ohata, T.: Stability of drifting snow-type perennial snow patches, Bull. Glaciol. Res., 21, 1-8, 2004

Glen, J. W.: The creep of polycrystalline ice, P. Roy. Soc. Lond. A Mat., 228, 519-538, 1955.

Grosjean, M., Suter, P. J., Trachsel, M., and Wanner, H.: Ice-borne prehistoric finds in the Swiss Alps reflect Holocene glacier fluctuations, J. Quat. Sci., 22, 203-207, 2007.

Haeberli, W., Frauenfelder, R., Kääb, A., and Wagner, S.: Characteristics and potential climatic significance of "miniature ice caps" (crest- and cornice-type low-altitude ice archives), J. Glaciol., 50, 129-136, 2004.

Hamran, S.-E., Øyan, M. J., and Kohler, J.: UWB radar profiling reveals glacier facies, Proceedings of the 2009 5th International Workshop on Advanced Ground Penetrating Radar, University of Granada, Granada, Spain, 27-29 May, 2009.

Hansen, J. P. H., Meldgaard, J., and Nordquist, J.: Qilakitsoq, De Grønlandske mumier fra 1400-tallet, Nuuk and Copenhagen: Grønlands Landsmuseum/Christian Ejlers' forlag, 216 pp., 1985.

Hare, G. P., Thomas, C. D., Topper, T. N., and Gotthardt, R. M.: The archaeology of Yukon ice patches: New artifacts, observations, and insights, Arctic, 65, 118-135, 2012.

Harris, C., Arenson, L. U., Christiansen, H. H., Etzelmuller, B., Frauenfelder, R., Gruber, S., Haeberli, W., Hauck, C., Holzle, M., Humlum, O., Isaksen, K., Kaab, A., Kern-Lutschg, M. A., Lehning, M., Matsuoka, N., Murton, J. B., Nozli, J., Phillips, M., Ross, N., Seppala, M., Springman, S. M., and Muhll, D. V.: Permafrost and climate in Europe: Monitoring and modelling thermal, geomorphological and geotechnical responses, Earth Sci. Rev., 92, 117-171, 2009.

Hauck, C., Isaksen, K., Vonder Mühll, D., and Sollid, J. L.: Geophysical surveys designed to delineate the altitudinal limit of mountain permafrost: an example from Jotunheimen, Norway, Permafrost Periglac., 15, 191-205, 2004.

Hipp, T., Etzelmüller, B., Farbrot, H., Schuler, T. V., and Westermann, S.: Modelling borehole temperatures in Southern Norway - insights into permafrost dynamics during the 20th and 21 st century, The Cryosphere, 6, 553-571, doi:10.5194/tc-6-553-2012, 2012.

Huss, M. and Fischer, M.: Sensitivity of Very Small Glaciers in the Swiss Alps to Future Climate Change, Front. Earth Sci., 4, 34, doi:10.3389/feart.2016.00034, 2016.

Imhof, M.: Modelling and Verification of the Permafrost Distribution in the Bernese Alps (Western Switzerland), Permafrost Periglac., 7, 267-280, 1996.

Isaksen, K., Hauck, C., Gudevang, E., Ødegård, R. S., and Sollid, J. L.: Mountain permafrost distribution on Dovrefjell and Jotunheimen, southern Norway, based on BTS and DC resistivity tomography data, Norsk Geogr. Tidsskr., 56, 122-136, 2002.

Isaksen, K., Heggem, E. S. F., Bakkehøi, S., Ødegård, R. S., Eiken, T., Etzelmüller, B., and Sollid, J. L.: Mountain permafrost and energy balance on Juvvasshøe, southern Norway, 8th International Conference on Permafrost, Zurich, Switzerland, 21-25 July, 2003, 467-472, 2003.

Isaksen, K., Ødegård, R. S., Etzelmuller, B., Hilbich, C., Hauck, C., Farbrot, H., Eiken, T., Hygen, H. O., and Hipp, T.: Degrading mountain permafrost in southern Norway - spatial and temporal variability of mean ground temperatures 1999-2009, Permafrost Periglac., 22, 361-377, 2011.

Jenk, T. M., Szidat, S., Schwikowski, M., Gaggeler, H. W., Wacher, L., Synal, H.-A., and Sauer, M.: Microgram level radiocarbon $\left({ }^{14} \mathrm{C}\right)$ determination on carbonaceous particles in ice, Nucl. Instrum. Meth. B, 259, 518-525, 2007.

Jenk, T. M., Szidat, S., Bolius, D., Sigl, M., Gäggeler, H. W., Wacker, L., Ruff, M., Barbante, C., Boutron, C. F., and Schwikowski, M.: A novel radiocarbon dating technique applied to an ice core from the Alps indicating late Pleistocene ages, J. Geophys. Res., 114, D14305, doi:10.1029/2009JD011860, 2009.

Kawasaki, K., Yamada, T., and Wakahama, G.: Investigation of internal structure and transformational processes from firn and ice in a perennial snow patch, Ann. Glaciol., 18, 117-122, 1993.

Kjøllmoen, B., Andreasse, L. M., Elvehøy, H., Jackson, M., and Giesen, R. H.: Glaciological investigations in Norway 2010, Norwegian Water Resources and Energy Directorate, Oslo, Norway, 106 pp., 2011.

Kneisel, C.: Occurrence of surface ice and ground ice/permafrost in recently deglaciated glacier forefields, St. Moritz area, Eastern Swiss Alps, Yellowknife, Canada, 575-581, 1998.

Laumann, T. and Reeh, N.: Sensitivity to climate change of the mass balance of glaciers in southern Norway, J. Glaciol., 39, 656-665, 1993.

Lee, C. M.: Withering snow and ice in the mid-latitudes: A new archaeological and paleobiological record for the Rocky Mountain region, Arctic, 65, 165-177, 2012.

Lehning, M., Löwe, H., Ryser, M., and Raderschall, N.: Inhomogeneous precipitation distribution and snow transport in steep terrain, Water Resour. Res., 44, W07404, doi:10.1029/2007WR006545, 2008.

Lilleøren, K., Etzelmuller, B., Schuler, D. V., Gisnås, K., and Humlum, O.: The relative age of mountain permafrost - estimation of Holocene permafrost limits in Norway, Global Planet. Change, 92-93, 209-223, 2012.

Marks, D., Kimball, J., Tingey, D., and Link, T.: The sensitivity of snowmelt processes to climate conditions and forest cover during rain-on-snow: a case study of the 1996 Pacific Northwest flood, Hydrol. Proc., 12, 1569-1587, 1998.

Matthews, J. A. and Dresser, P. Q.: Holocene glacier variation chronology of the Smørstabbtinden massif, Jotunheimen, southern Norway, and the recognition of century- to millennial-scale European Neoglacial events, The Holocene, 18, 181-201, 2008.

Meulendyk, T., Moorman, B. J., Andrews, T. A., and Mackay, G.: Morphology and Development of Ice Patches in Northwest Territories, Canada, Arctic, 65, 43-58, 2012.

Mott, R., Daniels, M., and Lehning, M.: Atmospheric Flow Development and Associated Changes in Turbulent Sensible Heat Flux over Patchy Mountain Snow Cover, J. Hydrometeorol., 16, 13151340, 2015.

Mott, R., Egli, L., Grünewald, T., Dawes, N., Manes, C., Bavay, M., and Lehning, M.: Micrometeorological processes driving snow 
ablation in an Alpine catchment, The Cryosphere, 5, 1083-1098, doi:10.5194/tc-5-1083-2011, 2011.

Nesje, A.: Latest Pleistocene and Holocene alpine glacier fluctuations in Scandinavia, Quaternary Sci. Rev., 28, 2119-2136, 2009.

Nesje, A., Pilø, L. H., Finstand, E., Solli, B., Wangen, V., Ødegård, R. S., Isaken, K., Støren, E., Bakke, D. I., and Andreasse, L. M.: The climatic significance of artefacts related to prehistoric reindeer hunting exposed at melting ice patches in southern Norway, The Holocene, 22, 485-496, 2012.

Norwegian Meteorological Institute: Meteorological data for stations Juvvasshøe (15270) and Fokstugu (16610), available at: http://eklima.met.no/, 2016.

Ødegård, R.: Ground and glacier thermal regimes related to periglacial and glacial processes: Case studies from Svalbard and southern Norway, Dr. Scient, Department of Geography, Rapportserie i naturgeografi, University of Oslo, Norway, 44 pp., 1993.

Ødegård, R., Nesje, A., Isaken, K., and Eiken, T.: Perennial ice patch studies - preliminary results from a case study in Jotunheimen, southern Norway, Geophysical Research Abstracts Vol. 13, EGU2011-12027, 2011.

Paterson, W. S. B.: The Physics of Glaciers, Pergamon, 3rd Edn., p. $97,1994$.

Pohl, S., Marsh, P., and Liston, G. E.: Spatial-Temporal Variability in Turbulent Fluxes during Spring Snowmelt, Arct. Antarct. Alp. Res., 38, 136-146, 2006.

Reckin, R.: Ice Patch Archaeology in Global Perspective: Archaeological Discoveries from Alpine Ice Patches Worldwide and Their Relationship with Paleoclimates, J. World Prehist., 26, 323-385, doi:10.1007/s10963-013-9068-3, 2013.

Reimer, P. J., Barad, E., Baykuss, A., Beck, J. W., Blackwell, P. G., Bronk Ramsey, C., Buck, C. E., Cheng, H., Edwards, R. L., Friedrich, M., Grootes, P. M., Guilderson, T. P., Haflidason, H., Hajdas, I., Hatte, C., Heaton, T. J., Hoffmann, D. L., Hogg, A. G., Hughen, K. A., Kaiser, K. F., Kromer, B., Manning, S. W., Niu, M., Reimer, R. W., Richards, D. A., Scott, E. M., Southhon, J. R., Staff, R. A., Turney, C. S. M., and van der Plicht, J.: IntCal13 and Marine13 radiocarbon age calibration curves $0-50,000$ years cal BP, Radiocarbon, 55, 1869-1887, 2013.

Rogers, S. R., Fischer, M., and Huss, M.: Combining glaciological and archaeological methods for gauging glacial archaeological potential, J. Archaeol. Sci., 52, 410-420, 2014.

Ruff, M., Fahrni, S., Gäggeler, H. W., Hajdas, I., Suter, M., Synal, H.-A., Szidat, S., and Wacker, L.: On-line radiocarbon measurements of small samples using elemental analyzer and MICADAS gas ion source, Radiocarbon, 52, 1645-1656, 2010.

Saloranta, T. M.: Simulating snow maps for Norway: description and statistical evaluation of the seNorge snow model, The Cryosphere, 6, 1323-1337, doi:10.5194/tc-6-1323-2012, 2012.
Sato, A., Takahashi, S., Naruse, R., and Wakahama, G.: Ablation and Heat Balance of the Yukikabe Snow Patch in the Daisetsu Mountains, Hokkaido, Japan, Ann. Glaciol., 5, 122-126, 1984.

Sigl, M., Jenk, T. M., Kellerhals, T., Szidat, S., Gaggeler, H. W., Wacher, L., Synal, H.-A., Boutron, C., Barbante, C., Gabrieli, J., and Schwikowski, M.: Towards radiocarbon dating og ice cores, J. Glaciol., 55, 985-996, 2009.

Sollid, J. L., Holmlund, P., Isaksen, K., and Harris, C.: Deep permafrost boreholes in western Svalbard, northern Sweden and southern Norway, Norsk Geogr. Tidsskr., 54, 186-191, 2000.

Sørdal, I.: Kartlegging av temperaturtilhøva i Gråsubreen og Juvfonne, Master, Department of Geosciences, University of Oslo, Oslo, 81 pp., 2013.

Spindler, K.: The Man in the Ice: The Preserved Body of a Neolithic Man Reveals the Secrets of the Stone Age, Crown Publishers, New York, 305 pp., 1994.

Suter, P. J., Hafner, A., and Glauser, K.: Lenk - Schnidejoch, Funde aus dem Eis - ein vor- und frühgeschichtliche Passübergang, Archäologie im Kanton Bern, 6, 499-516, 2005.

Tachon, M.: Thermal regimes and horizontal surface velocities on Hellstugubreen and Storbreen, Jotunheimen, Southern Norway, Master, Department of Geosciences, University of Oslo, Oslo, 99 pp., 2015.

Uglietti, C., Zapf, A., Jenk, T. M., Szidat, S., Salazar, G., and Schwikowski, M.: Radiocarbon dating of glacier ice, The Cryosphere Discuss., doi:10.5194/tc-2016-160, in review, 2016.

UNESCO: Perennial ice and snow masses - a guide for compilation and assemblage of data for the World Glacier Inventory, Technical Papers in Hydrology, 1, 59 pp., 1970.

Vedeler, M. and Jørgensen, L. B.: Out of the Norwegian glaciers: Lendbreen - a tunic from the early first millennium AD, Antiquity, 87, 788-801, 2013.

Westermann, S., Schuler, T. V., Gisnås, K., and Etzelmüller, B.: Transient thermal modeling of permafrost conditions in Southern Norway, The Cryosphere, 7, 719-739, doi:10.5194/tc-7-7192013, 2013.

Winsvold, S. H., Andreassen, L. M., and Kienholz, C.: Glacier area and length changes in Norway from repeat inventories, The Cryosphere, 8, 1885-1903, doi:10.5194/tc-8-1885-2014, 2014.

Zapf, A., Nesje, A., Szidat, S., Wacker, L., and Schwikowski, M.: ${ }^{14} \mathrm{C}$ measurements of ice samples from the Juvfonne ice tunnel, Jotunheimen, Southern Norway - validation of a ${ }^{14} \mathrm{C}$ dating technique for glacier ice, Radiocarbon, 55, 571-578, 2013.

Zhang, Y. L., Perron, N., Ciobanu, V. G., Zotter, P., Minguillón, M. C., Wacker, L., Prévôt, A. S. H., Baltensperger, U., and Szidat, S.: On the isolation of OC and EC and the optimal strategy of radiocarbon-based source apportionment of carbonaceous aerosols, Atmos. Chem. Phys., 12, 10841-10856, doi:10.5194/acp-12-10841-2012, 2012. 